\title{
Fordítva: Nyugati társadalomfilozófiai koncepciók és terminusok ,japanizációja" a korai Meiji érában
}

\author{
„Civilizációnk ma olyan, \\ mintha úgymond a tüz vízzé változna, \\ a nincsből [ $m u$ 無] átlépnénk a vanba [yū 有] [...]” \\ Fukuzawa Yukichi: Bunmeiron no gairyaku ${ }^{1}$
}

\section{A kérdés}

Mára a japán történelem számos kutatója egyetért abban, hogy a Meiji-kort 明治時代 (1868-1912) fémjelző politikai, gazdasági, társadalmi és kulturális átalakulás számos feltétele a Tokugawa-korban 徳川時代 (1600-1868) alakult ki, vagyis bár a „modernizáció” kétségkívül óriási változást idézett elő, „a változások sikere Japánban a nagyfokú kontinuitásban rejlik”. ${ }^{2}$ Ez persze nem azt jelenti, hogy a sóguni rendszerben tudatosan készítették volna elö az átalakulást, amely a kaikoku 開国 (,,az ország [Nyugat elötti] megnyitása”), így a nyugati intézményrendszerrel, technikával és társadalomképpel való találkozás után végbement. Akik azonban e változások eszmei és materiális kereteit a Meiji-korban alakították, korántsem szakadtak el a tradíciótól olyan nagy mértékben, mint azt első pillantásra gondolnánk, és mint azt közülük sokan állították. E tanulmányban arra a kérdésre keresem a választ, hogy milyen módon jelenik meg a radikális(nak ható) újítás és a hagyományhoz való szoros kapcsolódás e kettőssége a bunmei kaika 文明開化 („,civilizáció és felvilágo-

* _ Az Emberi Erőforrások Minisztériuma ÚNKP-16-3 kódszámú Új Nemzeti Kiválóság Programjának támogatásával készült. ORCID: 0000-0003-2713-7827. Ezúton köszönöm meg Kósa Gábor, Szabó Balázs és Várnai András értékes tanácsait, melyek nagy segítségemre voltak a tanulmány elkészítésében.

$1 「 今$ 「今゙文明はいわゆる火より水に変じ、無より有に移らんとするもの にて [...]」(Fukuzawa 1984b: 150).

2 Farkas 2012: 79, lásd még Farkas 2016: 214-216, és az e helyeken hivatkozott irodalmat. 
sodás”) mozgalmának idején a kor gondolkodását meghatározó szerzők nyugati munkákból készült fordításaiban, illetve vonatkozó elméleti írásaikban. A vizsgálat fókuszában azok a társadalomfilozófiai terminusok állnak, melyeket a Meiji-kor gondolkodói fordításaikban és saját írásaikban ,japanizáltak". E szóhasználattal arra utalok, hogy „fordításon” a következőkben a szó legtágabb értelmében vett ,át-vitelt (trans-ferre)"3 kell értenünk. Ezen értelmezés szükségességére mutat rá Ōhashi Ryōsuke 大橋良介, aki a jelen tanulmányban is központi kérdést a következő analógiában fogalmazta meg:

Egy más éghajlatú vidékről vagy talajból származó növény átültetése [Verpflanzung] után ismét gyökeret ver a számára idegen talajban, megváltozott éghajlati viszonyok között, s ugyanaz a növény marad akkor is, ha alakja a körülmények hatására nagyban megváltozik. Mi történik azonban, ha ugyanaz a szőlővessző, például egy tramini, badeni talajban nőve zamatos és erős, Elsaßban viszont nagyon száraz bort ad? A szőlővessző esetében tehát nem az alak, hanem az íz a döntő, a „spiritusz”. Vajon a badeni tramini e szellemét [Geist] átültetik [übersetzt] Elsaßba, vagy elvész? ${ }^{4}$

Kérdésem tehát az, hogy milyen céllal, milyen nehézségekkel szembesülve, illetve milyen módon fordították le, át, esetleg visszájukra a korai Meiji-kor gondolkodói az olyan, Japánban korábban ismeretlen vagy csak részlegesen ismert terminusokat és képzeteket, mint a nyugati istenfogalom, a „természetjog”, vagy a „szabadság” („freedom”, „liberty”). Fő forrásaim egy-egy nyugati mű e korban készült japán fordítása, illetve a Meirokusha 明六社 (Meiji Hat Társaság) gondolkodóinak - elsősorban a Meiroku Zasshi 明六 雑誌 lapjain ${ }^{5}$ megjelenő - írásai lesznek.

\section{Öneszmélés}

Mint ismeretes, az első nagyszabású Meiji-kori nyugati küldöttség, az Iwakuradelegáció (Iwakura shisetsudan 岩倉使節団, 1871-1873) Japánba való visz-

Ōhashi 1999: 129

4 Ōhashi 1999: 136. A szójáték (a növény átültetése és a fordítás értelmében vett „átültetés") a németben nincs meg.

5 A továbbiakban az „MRZ x:y.” rövidítéssel megadott hivatkozások e folyóiratot, a számot és az oldalszámot jelölik. 
szatérése „új korszak kezdetét jelentette”. ${ }^{6}$ A jelen tanulmány keretei között nem vizsgálhatom az e korszakban végbemenő számos változást, kizárólag az eszmetörténeti folyamatokra, vagyis egy viszonylag szük, de Japán átalakulásában annál nagyobb szerepet játszó csoport reflexiójának egyes aspektusaira szorítkozom. ${ }^{7}$ E csoport számára a Nyugattal való „találkozás” rendkívül intenzív, tettre késztető (vélt vagy valós) felismerések sorozatát jelentette. Fel kell mármost tennünk a kérdést, hogy a nyugati minták „letaglózó” hatása miért nem jelentkezett korábban, a Nyugat tanulmányozásának a Tokugawa-kor második felében igen széles körben elterjedt formája, a rangaku 蘭学 révén, amely önmagában ,holland tudományt” jelent ugyan, valójában a Hollandián, így a holland nyelven keresztül beáramló „nyugati” tudomány különböző szegmenseinek vizsgálatát takarja, ${ }^{8}$ ez az ország ugyanis a Tokugawa bakufu 徳川幕府 Nyugattal szembeni ellenségességének hosszú időszakában is kapcsolatban maradt Japánnal. Vajon a nyugati ismeretek menynyisége volt-e tehát a Meiji-kori „sokkélmény” oka?

Amikor 1867 öszén a bakufu visszaszolgáltatta a hatalmat a császári udvarnak (taisei hōkan 大政奉還), nem pusztán a Tokugawa klán bő 250 éves uralma ért véget, hanem a sóguni kormányzatok - a Minamotók 源 uralmával kezdődő - több mint fél évezredes sora is. ${ }^{9}$ Ez a nagyjából 700 év persze egyáltalán nem nevezhető egységesnek: számos belső, szemléletmódbeli változás következik be a 13. században még mindig élö, a bakufu vezetöit a

6 Fält 2005: 113.

7 Nem tárgyalhatom itt bővebben a kérdést, mennyiben volt közvetlen az a hatás, amelyet a Meiji-kori értelmiség a japánok gondolkodására kifejtett. Mint Huish rámutat (lásd Huish 1972), a „felvilágosítók” (keimōsha 啓蒙者) szerepét a hagyomány hajlamos túlértékelni; Swale pedig hangsúlyozza, hogy az európai felvilágosodás gondolkodóiról általánosan kialakult képpel való - a terminusok által is sugallt - azonosításuk számos esetben torzít (Swale 2000: 71-72). Az ugyanakkor vitathatatlan, hogy a következőkben vizsgált szövegek japánra ültetésével, a nyugati filozófiai szövegek értelmezésének elindításával, számos új terminus „meghonosításával” hosszú távon és nagymértékben befolyásolták a 20. századi japán gondolkodást.

8 Vö. Jansen 2007: 91-92. A szakirodalomban sakoku 鎖国 (,zárt ország”) néven emlegetett berendezkedés a bakufu uralmának első szakaszában alakul ki. Már Tokugawa Ieyasu 徳川家康 (1542-1616) is bevezetett korlátozó rendelkezéseket elsősorban az ibériai hittérítők tevékenysége ellen, az ő tanításukat ugyanis összekapcsolták bizonyos Tokugawa-ellenes megmozdulásokkal. A rendelkezések erőskezü foganatosítására csak az 1620-as, '30-as években került sor. Ezután csak a kereskedelmi tevékenységet folytató hollandok maradhattak Japánban (Totman 2006: 303-304).

9 Jamadzsi 1989: 255. 
hagyományos, vérségi értelemben is az irányításuk alá tartozó terület „atyáinak" tekintő felfogástól ${ }^{10}$ addig a Yamaga Sokōnál 山鹿素行 (1622-1685) kibontakozó nézetig, melyben a szamuráj-lét „hivatásként” jelenik meg (shokubunshugi 職分主義). ${ }^{11} \mathrm{E}$ társadalmi változások során azonban egyre jelentősebb szerepet kap az a szemléletmód, mely az általunk vizsgált korszak előzményét jelentő Edo-korban a vezető réteg gondolkodásának mintegy „esszenciájává" válik: a bushi 武士 réteg, a harcos-írástudók kötelességorientált életfelfogása, az alá-fölérendeltségi viszonyok szilárd (s megbomlásuk esetén újra helyreállítandó) rendjének fenntartása harcosként és az igazgatás szereplöjeként egyaránt. Ez az értékrend nagymértékben különbözik azoktól az eszméktől, amelyek az európai, illetve az amerikai gondolkodásmódot már a 18. század forradalmai óta erőteljesen meghatározták. Fenti kérdésünket ennek tükrében úgy fogalmazhatjuk át, nem okozott-e a nyugati gondolkodásmóddal a rangakun keresztül való találkozás megrázkódtatást a mindaddig szinte kizárólag kínai (vagy legalábbis Japánba Kínából érkező) ismeretekkel foglalkozó gondolkodóknak már a Tokugawa-korban is? A válasz kettős. Bizonyos értelemben ugyanis természetesen okozott: a nyugati tudomány egyes ágainak eredményeit Japán tudósai igen nagyra becsülték, és igyekeztek minél mélyebben megismerni azokat, elmaradottnak érezvén saját tudományos fejlettségüket. Ez azonban nem jelenti, hogy megkérdőjelezték volna azt a társadalmi rendet és a hátterét alkotó tradicionális gondolkodásmódot, melyekbe ez a tudományosság illeszkedett: a Nyugatról átvett ismeretek túlnyomó része a szó klasszikus értelmében véve technikai jellegü volt (különösképp kiemelkedtek közülük az orvostudomány és az anatómia, illetve a hadtudomány fejleményei ${ }^{12}$ ). Megvilágító e tekintetben az az eset, amelyet Hirakawa ír le Sugita Genpaku 杉田玄白 (1733-1817) kapcsán, aki egy boncolás után azt a „tudatlanságot” ostorozza, mellyel korábban legfőbb feladatát, ura szolgálatát ellátta. „Számos szerző - mondja Hirakawa - öszszekapcsolja a holland tudományt a feudális uralomhoz való kritikus hozzáállással, itt azonban egyik legelhivatottabb támogatóját látjuk lesújtva a »szégyentől«, mely abból származik, hogy nem megbízhatóan látta el »ura szol-

10 Lásd Morimoto 2009: 244.

11 Lásd Szabó 2015: 38-39. A bushi réteg mint réteg kialakulásáról lásd Szabó 2016: $13-14$.

12 Katō 1991: 344. Részletesen lásd Clements 2015: 151-154. 
gálatát«."13 A Nyugat „fejlettsége” tehát, legalábbis ami a rangaku elterjedésének korai szakaszát illeti, nem a bushi morálon alapuló társadalmi rend megkérdőjelezését okozza, hanem olyan „szégyent”, amely éppenséggel tökéletesen illeszkedik a bushi morálba. Kétségtelen, hogy a rangaku - illetve a „nyugati tudomány”, a yōgaku 洋学 elődjének tekinthető eigaku 英学 (,,angol tudomány") ${ }^{14}$ - térnyerése az oktatás terjedésével együtt meghatározó előzményét jelentette a Meiji-kori átalakulásnak. Ahhoz azonban, hogy a nyugati eszmék mint az emberek közötti viszonyok és a morál tudatos, aktív átalakítására használt eszközök elemi hatást fejhettek ki a Tokugawa-kor külkapcsolatokat erősen korlátozó évszázadai után, döntően hozzájárult a bakuhan 幕藩 rendszer 19. század közepére bekövetkező megroppanása. Nem az ekkor megjelenő új tudományágakból származó ismeretek mennyisége okozta tehát a korai Meiji-kor írástudóinak megrázkódtatását, hanem hogy a vélt vagy valós „elmaradottság” felett érzett szégyen már nem a bushi szégyene volt. A Meijikori filozófiai nyelv kialakításában kulcsszerepet játszó Nishi Amane 西周 (1829-1897), jóllehet, a japán elmaradottság apológiájaképp, mégis meglepő hangnemben ír a konfuciánus mủveltség színvonaláról:

Úgymond tudományunk hét-nyolc évvel ezelőttig ki sem lépett a négy könyv és az öt klasszikus köréböl, de a négy mester és a hat klasszikus is csupán játékszer volt: a legalsó fokon egy szinten a teaszertartással és az ikebanával, a legmagasabb fokon pedig az íj, a ló, a kard és a lándzsa [technikáival]. ${ }^{15}$

Itt érhető tetten az a minőségi változás, amely a Meiji-kor átalakulását jellemzi.

Ez az ,átalakulás” persze önmagában is ellentmondásos. Kettőssége szimbolikusan abban a kérdésben foglalható össze, hogy a japánul „Meiji ishinként”明治維新 ismert folyamatot „Meiji restauráció”, „Meiji forradalom” (revolution) vagy valamilyen ezektöl különböző névvel illessük-e. Jansen és Rozman, akik az „átmenet/átalakulás” (transition) mellett teszik le voksukat,

13 Hirakawa 2007: 440.

14 Lásd Numata 1989: 215. Numata is rámutat, hogy a folyamat, mely a Meiji-korban teljesedik ki, már a 18. század végén elindul, igaz, ekkor még csak igen szük területen (elsősorban a nagaokai eigakura kell gondolnunk).

15 「所謂學術ナル者七、八年前マデ四書五經/範圍二出ズ而テ其四子六經ス ラ唯玩具之ヨ卑ウシてハ茶ノ湯生花卜肩习並べ之ヨ高ウシテ弓馬刀劍槍卜 相伯仲シタル耳」(MRZ 2:5. Vö. Kōno 2011: 21). 
rámutatnak, hogy a Japánban lezajló folyamat több tekintetben is lényegileg tér el mind Ázsia más országai (Kína, Oroszország), mind Európa és Amerika „államépítéssel összekapcsolt átalakulásaitól” ${ }^{16}$ Ha például az 1789-es francia forradalom eseményeire és az ezeket kiváltó közhangulatra gondolunk, adná magát a párhuzam a francia és a japán „köznép” általános elégedetlensége között - csakhogy miközben a franciák az amerikai forradalmat csodálva a királyi egyeduralom megszüntetését sürgették, a bakufu ellen lázító shishik 志士 „az uralkodó tiszteletére és az idegenek kiüzésére” (sonnō jōi 尊皇 攘夷) szólítottak fel. ${ }^{17}$ „Meiji forradalomról” beszélni tehát félrevezető volna. Ha ugyanakkor tekintetbe vesszük, hogy az új érában, noha a „régi” - vagyis a császári - hatalmat állították helyre, ám az ország intézmény- és igazgatási rendszerét nyugati mintára alakították át, csúsztatásnak tünik a folyamatot a szó Nyugaton bevett értelmében „restaurációnak” nevezni. Szerencsés talán ezért, ha a „Meiji-megújulás” szókapcsolatot használjuk, utalva arra, hogy az 1870-es évek átalakulásának fö sajátossága a számos területen megjelenő „forradalmi” változás és ezzel együtt a császári hatalom újjáélesztése volt, ahogy Eisenstadt fogalmaz: a „forradalmi restauráció” (revolutionary restauration).$^{18}$ E kettőséget azért is különösen adekvát hangsúlyozni, mert a számunkra központi jelentőségü gondolkodók, vagyis azok, akik a korai Meiji-korban legvehemensebben sürgették az átalakulást, így például az időszak talán legnagyobb hatású alakja, Fukuzawa Yukichi 福沢諭吉 (1834-1901), vagy a Meiji Hat Társaság alapítója, Mori Arinori 森有礼 (1847-1889), maguk is bushi családból származtak, bushi neveltetésben részesültek. A Meiji-kor elején ők voltak azok, akik úgy látták, nem pusztán a nyugati tudomány eredményeit, hanem e tudományosság intézményes és társadalmi kereteit is „le kell fordítaniuk”, át kell vinniük (,trans-ferre”) saját társadalmi-kulturális közegükbe. Jól szemlélteti ezt, hogy Fukuzawa híres írásának, a Gakumon no susuménak 学問のす \ (,A tudomány előremozdítása”, 1872-76) a nyitómondata, mely szerint „,[m]int mondják, »az ég nem

16 Jansen - Rozman 1988: 9.

17 Vö. Havens 1970: 13-14.

18 Eisenstadt 1996: 266 -277. Eisenstadt (1996: 266-269) szintén azt emeli ki, hogy a Meiji ishin számos tekintetben mutatott ugyan hasonlóságot a Nyugat nagy forradalmaival, melyekkel sokszor összehasonlítják, sok tekintetben azonban eltérő mintákat követett, ugyanakkor, a császári uralom „restaurációja” olyan struktúra kialakítását jelentette, amely abban a formában, ahogyan ekkor hivatkoztak rá, valójában soha nem létezett (uo. 271). 
teremti egyik embert a másik fölé[rendeltjévé], s nem teremti egyik embert a másik alá[rendeltjévé] «", ${ }^{19}$ a korszak ismert jelmondatává vált. ${ }^{20}$

Hogy miként kapcsolódik a nyugati republikanizmus itt megjelenő egyenlőség-fogalma ,a tudomány előremozdításához”, világossá válik a mű bevezetőjéből. Fukuzawa itt a különböző tudományterületeket (geográfia, történetés gazdaságtudomány, etika (shūshingaku 修身学) sorra véve kimondja:

[E] tudományok müvelése során minden nyugati munka fordítását [elkészítve] tanulmányoznunk kell [ezeket], elsősorban japán kanát használva, a fiatalok közül azok számára, akik tehetségesebbek, megjegyzéssel [yokomoji 横文字 ${ }^{21}$ ] ellátva; minden szakterület és tudomány hasznos dolgokkal [jitsugoto 実事] kell foglalkozzon, s az adott dolog vizsgálatában csakis arra kell irányítsa figyelmét; az elérhető dolgok törvényszerüségeit [dōri 道理] kutatva pedig fordítsa ezt a jelen hasznára. Ha az elmondottakat teszik az emberek általános gyakorlati tudományává [jitsugaku 実学], s minden ember, alsóbb és felsőbb rangúak megkülönböztetése nélkül, egyaránt részesül a megfelelő tudásból, ennek révén a hivatalnokok, földmüvesek, iparosok és kereskedők mind elvégzik a maguk feladatát, ki-ki folytatja a maga családi foglalkozását, s független lesz [dokuritsushi 独立し] az egyes [mi 身], független a család [ie 家], s független a birodalom és az állam [tenkakokka 天下国家 ${ }^{22}{ }^{23}$

$19\ulcorner$ 『は人の上に人を造らず人の下に人をつくらず』と言えり。」

(Fukuzawa 1984a: 51. Lásd ehhez Macfarlane 2013: 69).

20 Lásd ehhez Zhang 2010: 49. A Fukuzawa által lefordított amerikai Függetlenségi nyilatkozatra utaló parafrázis a konfucianizmus és a yōgaku viszonyának egyik legérdekesebb kérdését, az „ég” helyének problematikáját is felveti, erről lásd később.

21 Értsük itt az eredeti szöveg mellé írt fordítást, illetve a fordítás mellett feltüntetett eredeti szöveget.

22 Japán függetlensége elsősorban a külső hatásokkal szembeni ellenállás képességét jelenti, természetesen nem kizárólag szellemi („civilizációs”), hanem militáris értelemben is. Lásd Zhang 2010: 58.

23 「これらの学問をするに、いずれも西洋の翻訳書を取り調べ、たいていのこ とは日本の仮名にて用を便じ、あるいは年少にして文才ある者へは横文字を も読ませ一科一学も実事を押え、そのことにつきその物に従い、近く物事の 道理を求めて今日の用を達すべきなり。右は人間普通の実学にて、人たる者 は貴賤上下の区別なく、みなことごとくたしなむべき心得なれば、この心得 ありて後に、士農工商おのおのその分を尽くし、銘々の家業を㗬み、身も独 立し、家も独立し、天下国家も独立すべきなり。」(Fukuzawa 1984a: 52). 
Mindenkire kiterjedő és gyakorlatorientált - ezek a Fukuzawa által ideálisnak tekintett oktatási rendszer fő jellemzői, melyek mögött egyaránt felfedezhetjük a comte-i pozitivista tudományeszményt és a Millhez kapcsolható liberalizmust. E rendszer új intézményeit szintén az 1870-es évek elején alakították ki, nagymértékben támaszkodva a nyugati mintákra, melyeket az Európát és Amerikát megjárt gondolkodók interpretáltak. ${ }^{24}$ Ilyen értelmiségi volt maga Fukuzawa, vagy Mori Arinori is, aki amerikai tartózkodása során célzott kutatások, egyebek mellett egy akadémiai körökben kitöltetett kérdőív révén igyekezett ismereteket gyüjteni a hazai oktatási reformok elösegítéséhez. $^{25}$

Szintén az átalakulóban lévő japán oktatás, de nemcsak az ifjúság, hanem az egész japán nép hosszú távú és legtágabb értelemben vett oktatása állt annak hátterében is, hogy Mori Amerikából való hazatérése után azonnal felkereste a neves morálbölcselőt, Nishimura Shigekit 西村茂樹 (1828-1902), egy tudományos „társaság”, a hasonló nyugati society-k mintájára elképzelt csoport alapítására téve javaslatot. ${ }^{26}$ Ez a társaság lett a Meirokusha, azaz „Meiji Hat Társaság” (a név a hivatalos alapítási évből, 1874-ből, vagyis Meiji 6-ból származik), melynek már müködési alapelvei is figyelmet érdemelnek a jelen kontextusban. A társaság tagjainak elsődleges célja ugyanis az volt, hogy olyan csoportot hozzanak létre, melyet önálló individuumok alkotnak, akik nyílt és egyenrangú vitában (hatsuron 発論 $^{27}$ ) folytatnak eszmecserét az őket összekapcsoló problémákról. ${ }^{28}$ Ugyanabban az értelemben válnak tehát society-vé, ahogyan magát a japán népet is azzá akarják tenni (az angol society, akárcsak a latin societas szó, „társaságot” és „társadalmat” is jelent), miközben - írja Yanabu - „, [a] »fejedelemségben« és a »hanban« az emberek társadalmi státuszukban [mibun 身分] léteztek, nem pedig individuumként."29 Miközben tehát a kelet-ázsiai régió kultúráit alapvetően közösség-centrikusként szokás leírni, szemben a Nyugat évezredes hagyományokon nyugvó individualizmusával, ezen a ponton azt látjuk, hogy a japán értelmiség nyugaton sajátítja el a „társasági” jelleg e formáját. Ennek tükröződését látjuk

\footnotetext{
24 Az oktatási intézményrendszerhez lásd Rubinger 1988: 207-211.

25 Tozawa 1991: 6-7.

26 Tozawa 1991: 8-12, Okubo 2007: 227-230, Swale 2000: 70.

27 Tipikusan a Meiji-korban használt kifejezés.

28 Yanabu 2009a: 5-6.

$29\ulcorner 『$ 国』や『藩』では、人々は身分として存在しているんであって、個人と してではない。」(Yanabu 2009a: 6).
} 
a Meirokusha célkitüzéseiben. Ahogyan az alapító okirat első cikkelyében fogalmaznak:

[A] társaság [sha 社] megalapításának fő célja összekapcsolni azokat, akik vállalkoznak országunk oktatásának fejlesztésére, hogy e [folyamat] eszközeiről tanácskozzanak, továbbá, hogy a hasonló meggyőződésűek összegyűlve eszmét cserélhessenek eltérő nézeteikről, terjesztve a tudást [chi 知], világossá téve a tudatot [shiki 識]. ${ }^{30}$

Tévedünk azonban, ha e magasztos és egybehangzó célkitüzések nyomán tökéletes harmóniát feltételezünk a Meirokusha gondolkodói között. Fukuzawa például a tudomány müvelőinek feladatáról szóló 1874-es tanulmányában, melyet eredetileg a Meirokusha folyóiratában, a Meiroku Zasshiban tervezett megjelentetni, ám ehelyett a fent idézett Gakumon no susume 4. részeként tett közzé, erősen bírálja azokat az értelmiségieket, akik a kormányzat szolgálatába állnak. ${ }^{31} \mathrm{~A}$ kritika a Társaság igen sok tagját érintette, így a Meiroku Zasshi teljes második számát az írás bírálatának szentelték. ${ }^{32}$ Noha e nyilvános vita önmagában szintén a Társaságot összekapcsoló eszmékből sarjadt, mind a szembenállás elvi oka, mind a mögötte meghúzódó, sokkal kevésbé elvi indokok ${ }^{33}$ visszamutatnak a fent említett kettősségre, amely az egész

30 「社习設立スルノ主旨八我国ノ教育を進メンか為二有志ノ徒会同シテ其 手段习商議スル二在リ又同志集会シテ異見习交換シ知习広メ識 习明二ス ル二在り」(Meirokusha seiki 明六社制規, idézi Okubo 2007: 71).

31 Fukuzawa 1984a: 66.

32 Vö. Howland 2002: 40-45. Mori Fukuzawa-kritikájához lásd Swale 2000: 73-75. Howland (2002: 42-43) felhívja rá a figyelmet, hogy a két, a korban alapvetően hasonló jelentésü szóból álló bunmei kaika 文明開化 összetétel e vita nyomán bizonyos mértékben meghasad, amennyiben az előbbi elsősorban a - fukuzawai értelemben vett - „civilizációra” mint állapotra lesz használatos, az utóbbit pedig jellemzően társai használják a „civilizáció” mint - felülröl is irányított - tevékenység vonatkozásában. Fontos megjegyezni ugyanakkor, egyfelől, hogy a bunmei és a kaika eredetüket tekintve nem azonos konnotációkat idéznek, amennyiben a bunmei a klasszikus konfuciánus müveltséghez is kötődik (lásd Kōno 2011: 243), másfelől pedig, hogy a használat, illetve a két terminus megkülönböztetése az egyes gondolkodóknál több tekintetben mutat eltéréseket (lásd Kōno 2011: 241-248).

Mint Braisted felhívja a figyelmet, Fukuzawa általában is saját iskolája, a Keiō Gijuku 慶應義塾 folyóiratát, a Minkan Zasshit 民間雑誌 részesítette előnyben a Meirokuval szemben (lásd még Kōno 2011: 19-20), ami pedig bírálatát illeti, ,sem kormányától nem volt olyan független, sem kelet-ázsiai örökségétől nem volt oly mértékben mentes, mint gondolta" (Braisted 1976: xxiv.). Fukuzawát az intézmény helyzete miatt is rosszul érintették az új oktatásügyi intézkedések, lásd Rubinger 1988: 205. 
Meiji-megújulás atmoszféráját meghatározta, és amely a következőkben vizsgált nyelvi, illetve fordítástechnikai megoldások szempontjából is központi jelentőségü lesz. E tanulmány középpontjában ugyanis nem a Meirokusha képviselői közötti vállalt ellentétek, hanem a gondolkodásukban megjelenő belső feszültségek állnak, ahogyan ezek az egyes nyugati terminusok fordítási kísérleteiben tükröződnek.

\section{Betük helyett írásjegyek}

A Meiji-kori fordításokban alapvetően négy módja volt a japánban meg nem lévő nyugati terminusok átültetésének: 1) a rangaku idején létrejött terminusok alkalmazása; 2) az adott terminus kínai fordításának átvétele (ha létezett már ilyen); 3) a klasszikus kínai nyelvben meglévő elemek alkalmazása az új kontextusban, új jelentéssel felruházva; 4) új összetételek megalkotása. ${ }^{34}$ Az első két esettel a következőkben kisebb mértékben foglalkozom, mivel ezekben a fordítók a nyugati szövegek kontextusához már korábban hozzáillesztett terminusokat alkalmaztak. A másik két módszer kapcsán, melyek köréből példáimat elsősorban venni fogom, fontos néhány elméleti megjegyzést tennem.

A klasszikus kínai nyelvből származó szavak/írásjegyek új értelemben való alkalmazása sokak számára ismerős lehet egy, a nyugati orientalisztikában szélesebb körben vizsgált példából: a jezsuita misszió latin-kínai fordításainak esetéböl. Mint arról többen írtak már, a jezsuiták ,akkomodációs” stratégiájának az volt a lényege, hogy a kínai bölcseleti hagyomány közegébe ágyazva fogadtassák el a kereszténységet Kínában, ezáltal a kínai bölcseletet nem „eretnek” tanként, hanem a keresztény tanítás „torzult” változataként értelmezve. Ennek egyik jellegzetes példája a Deus tianként 天 való fordítása, vagy a ratio átültetése a Song-kori konfucianizmusban központi jelentőségűvé váló libe 理. ${ }^{35}$ Matteo Ricci és társai eljárását az motiválta, hogy belátták, a kínai olvasó számára teljességgel idegen terminusok akkor lesznek valamelyest befogadhatók, ha azon a módon integrálják őket a belső keletkezésü hagyományba, ahogyan e hagyomány újítói is a klasszikusokban gyökerező szavakat (írásjegyeket) használták fel új gondolatok bevezetésére. Eközben

34 Katō 1991: 361-364 nyomán.

35 Lásd Brancaccio 2007: 54-63, Várnai 2011: 55-57. 
persze a terminusok eredeti értelme nagymértékben megváltozott, amit a jezsuiták jól tudtak, ám a tanítás terjesztése érdekében megkötötték ezt a kompromisszumot. A Meiji-kori értelmiség fordításainak célja azonban csak abban a tekintetben mutat párhuzamot a jezsuiták tevékenységével, hogy „nyugati”, alfabetikus írásrendszerben született szöveget fordítottak „keleti”, ideogrammatikus írásjegyekkel lejegyzett nyelvre. Céljuk azonban szinte ellentétes volt a jezsuitákéval: nem elfedni akarták a nyugati filozófiai terminusok újszerüségét, hanem éppenséggel azt akarták megmutatni, mennyire nagy szüksége van saját „felvilágosulatlan” kultúrájuknak erre az új típusú ismeretanyagra. Ettől függetlenül azonban a rendelkezésükre álló írásjegykészlet ugyanaz volt, amelyet a megelőző évszázadok során használtak. Éppen ez teszi izgalmassá fordításaikat e vizsgálat számára.

Itt kell megjegyeznem, hogy - mint Fukuzawa fenti soraiban is láttuk a Meiji-kor legelején felmerült a latin ábécé átvételének gondolata. A Meiroku Zasshi első számában Nishi Amane tíz érvet sorol fel emellett, melyek között - noha ez a legrövidebb pont - szerepel az az elöny is, hogy ,a művek fordítása sokkal könnyebb volna" az alfabétum átvételével. ${ }^{36}$ A nyílt vita szellemében Nishimura Shigeki ugyanitt megjelenő írásában Nishivel szemben érvel, de nem azzal, hogy a japán írásrendszert kell megtartani, hanem hogy míg „Nishi sensei magyarázata szerint az emberek hamis nézeteit csak az írásjegyek megújításával lehet eloszlatni”, az ő véleménye „az, hogy a hamis nézetek eloszlatása nélkül az írásjegyek megújítása nem lehetséges". ${ }^{37}$ Nishimura alapítótársa, Mori Arinori odáig megy, hogy a nyugati civilizáció számos más elemével együtt az angolnak mint a hivatalos kommunikáció elsődleges nyelvének a bevezetését is szorgalmazza. ${ }^{38}$ Mindeme kísérletek azonban csak felvetések maradnak: a Meiji-kori fordítások, mint mondtam, kanjikba ültetik át az európai és amerikai szövegek terminusait. Ez önmagában több kérdést vet fel.

Mindenki, aki megpróbált bármilyen, ideogrammatikus írásjegyekkel lejegyzett szöveget alfabetikus írásrendszert használó nyelvre fordítani, találkozott már azzal a dilemmával, hogy egy-egy összetétel esetén az egyes írásjegyek saját értelmét, majd ezek összetételét adja-e meg, vagy magáét az

$36\ulcorner$ [此法果シテ立夕八]著述燔譯甚便リ 7 得ン[其利]」MRZ 1:5. A vitához lásd Kōno 2011: 248-256.

37 MRZ 1:10. Nishimura olyan, máig a kanjik megtartása mellett szóló érveket is felsorakoztat, mint az azonosalakúság kérdése (uo. 10-11).

38 Lásd Katō 1991: 347-349, Facius 2012: 236, Swale 2000: 64-65. 
összetételét. ${ }^{39}$ Amikor például a tenshi 天子 (kínai tianzi) szót „uralkodóként” fordítjuk magyarra, „helyesen” járunk el abban az értelemben, hogy visszaadjuk azt, ami az összetétel egészben vett referenciája. Tudjuk viszont, hogy a 天 írásjegye magában hordozza az „ég” értelmet, a 子 a „gyermeket”, így gyakran élünk „,az ég gyermeke/fia” fordítással - ez azonban az avatatlan olvasó esetében magyarázatot kíván, miközben úgy tünik, a kínai vagy japán olvasó számára az írásjegyek önálló jelentése (,ég”, ,gyermek”) és az így kapott közös jelentés (,az ég gyermeke/fia”), illetve a tényleges referencia (,uralkodó") is felfejthető. Joggal érvelhetne persze valaki úgy, hogy ez a kettősség valójában az anyanyelvi olvasó számára sem jelenik meg: a kínai vagy japán olvasóban sem „sejlik fel” az összetétel két tagjának önálló jelentése, mivel az összetételt egészében „ismerik”. ${ }^{40}$ Ez a probléma részben átvezet a pszicholingvisztika területére, ahová e tanulmány keretei között semmiképp nem léphetek, fontos azonban megjegyezni, hogy a következőkben vizsgált példák e tekintetben különböző típusokat szemléltetnek. Egyes esetekben valóban azt fogjuk látni, hogy a fordítók éppenséggel úgy alkalmaznak egy-egy régi összetételt, hogy az csak eredeti jelentésétől elvonatkoztatva tölthet be többé-kevésbé hasonló szerepet, mint a forrásnyelvben (pl. jiy $\bar{u}$ 自由 mint ,,liberty”). Máskor viszont, épp ellenkezőleg, arra apellálva használnak egyes összetételeket, hogy az olvasó ismeri az alkotóelemek jelentését (pl. seihō 性法 mint „Naturrecht”). Számunkra mindkét esetben az a fó kérdés, hogy mennyiben módosít a japán terminus az eredeti jelentésen, de azt, hogy valamilyen mértékben mindenképp módosít rajta, már itt, elöljáróban le kell szögezni. ${ }^{41}$

Nemcsak a modern fordítástudományban ismeretes, hogy a fordítás soha nem jelenti „ugyanannak” a szövegnek egy másik nyelven való létrehozását. ${ }^{42}$ Még akkor is, ha a két nyelv kulturális közege térben és időben relatíve közel áll egymáshoz, mindig számolni kell azzal, hogy „,a célnyelvi befogadó az

39 A problémakör kapcsán vö. Takó 2013: 183-185.

40 Vö. Yanabu 2009b: 22.

41 Vö. Howland 2002: 18-25, 67-76. Az utóbbi szakaszban Howland izgalmas példákon mutatja be, hogy az „autenticitás” és az „érthetőség” (authenticity, accessibility) miként jelennek meg a korabeli fordításokban, vagyis hogy az egyes esetekben miként kerül előtérbe a forrásnyelvhez és annak gondolkodásmódjához való hüség, esetlegesen a könnyebb érthetőség rovására (autenticitás), s miként válik máskor elsődlegessé az aránylag nagyfokú érthetőség, háttérbe szorítva a forrásszöveghez való hüséget.

42 A fordíthatóság/fordíthatatlanság áttekintéséhez lásd Albert 2003: 43-69. Az ekvivalencia általános szaktudományos elemzéséhez lásd Klaudy 1994: 68-79. 
egyes szavakhoz saját kultúrájának valóságait (saját léttapasztalatát) társítja."43 Látnunk kell azonban azt is, hogy a számunkra itt központi jelentőségủ eset ezen az általában meglévő tényezőn kívül két további sajátossággal is rendelkezik. Az első, hogy a kínai eredetü írásjegyek (amennyiben nem tisztán hangértékükön jelennek meg a szövegben, de ezzel az esettel a Meiji-kor kontextusában nem kell számolnunk) több tekintetben másképp viselkednek, mint az alfabetikus lejegyzési rendszert használó nyelvek. Elsősorban nem arra gondolok, hogy ,piktografikusak” - ez a tulajdonságuk, ha még nem veszett is el teljes mértékben, alig játszik szerepet a Meiji-kori Japánban. Annál fontosabb viszont két másik mozzanat. Az egyik, hogy az írásjegyek - mondja Yanabu - még a mai anyanyelvi beszélő számára is bírnak egyfajta sajátos jelentőséggel, azzal a hatással, hogy még ha nem ismerjük is eredetüket, mintegy a „mélyükön” kell rejlenie valamilyen, a hétköznapi szóhasználatban nem feltétlenül tükröződő tartalomnak. ${ }^{44}$ A másik kiemelendő pont a fent már érintett eset, az összetételek kérdése. Ahogyan ugyanis az európai nyelvekre való fordítás során megfontoljuk, hogy egy szóval fordítsunk-e egyegy összetételt, a probléma a japánra való fordításkor is megjelenik, csakhogy miközben például a magyar „uralkodó” szó és „,az ég fia” szerkezet világosan különbözik egymástól grammatikailag, az írásjegy-összetételek esetében az európai nyelvészeti gondolkodást tradicionálisan uraló, elsősorban latin alapú kategóriák sokkal kisebb mértékben különíthetők el egymástól. Ez természetesen a kínai nyelv sajátosságaiból ered. ${ }^{45}$ Amikor például a „liberty” szóra valaki a jiyu 自由 fordítást alkalmazza, olyan „szót” használ egy másik szó fordítására, amely egyben grammatikai szerkezet is. A modern fordítástudomány felől ezt úgy fogalmazhatjuk meg, hogy egy látszólag csupán lexikai átváltási művelet „mögött”, vagy inkább azzal párhuzamosan, egy grammatikai átváltást is végrehajt. ${ }^{46}$ Természetesen vannak esetek, amikor a fordító tudja, hogy a forrásnyelvi szó is hasonló összetétel volt - Nishi Amane például a ,philosophy” eredeti görög jelentésének ismeretében igyekszik megtalálni a legmegfelelőbb fordítást ${ }^{47}$, nagyon sok esetben azonban a japán fordító akkor is összetételt alkalmaz, ha az eredeti terminus történetileg sem az.

\footnotetext{
43 Albert 2003: 62-63.

44 Yanabu 2009b: 23-24. Az alábbiakban vizsgált God-Shangdi megfeleltetés kapcsán ugyanehhez: Yanabu 2001: 242.

45 A kínai szófaj kérdéséhez lásd Mártonfi 1971, különösen: 242-243.

46 A fordításelméleti kategóriákhoz lásd Klaudy 1994: 105, 155-156.

47 Lásd pl. Ōhashi 1999: 133.
} 
Ennek egyszerüen az az oka, hogy a Meiji-kor japán gondolkodói olyan esetek tömegével találták szemben magukat, melyekben nem egyszerủen arról volt szó, hogy a forrásnyelvi terminus és célnyelvi megfelelőjének jelentésmezője nem fedték egymást, hanem arról, hogy az adott nyelvi elem, minden konnotációjával és kulturális vonatkozásával együtt, nem volt meg a rendelkezésükre álló készletben. ${ }^{48}$ Ennek, mint Howland hangsúlyozza, rendkívül nagy gyakorlati szerepe volt a Meiji-megújulás időszakában.

A fogalmak [concepts], melyek a nyugatiasítás tartalmát meghatározták, nem voltak jól fordíthatók; nem illeszkedtek természetesen módon a meglévő japán fogalmakhoz. [...] A Nyugat lefordítására tett japán kísérletek egyaránt értendők nyelvi problémaként - új fogalmak létrehozása és elterjesztése - és a cselekvés problémájaként - az új fogalmak alkalmazása a nyugatiasodó Japánban bevezetendő irányelvekröl [policies] szóló vitákban. ${ }^{49}$

A következőkben mind a japán (illetve a kínai) eszmetörténetben már meglévő terminusok ,új” alkalmazásakor, mind az új összetételek megalkotásakor arra keresem a választ, hogy milyen módon játszott szerepet a fordításban az említett sajátosságok találkozása, vagyis hogy az ,ismert” értelmet felhasználták, figyelmen kívül hagyták vagy megkísérelték kizárni az ismeretlen fogalmak japánra való átültetésekor.

\section{Megújuló és/vagy elveszett értelem}

\section{Isten és 天}

Nem pusztán azért utaltam az imént a jezsuita fordítókra, mert történetük részleges párhuzamot mutat az általam itt vizsgált történettel, hanem azért is, mert számos esetben ugyanazokkal a konkrét fordítási problémákkal szembesültek, mint a Meiji-megújulás gondolkodói. Ennek legeklatánsabb példája az esszenciálisan monoteista keresztény vallás isten-koncepciójának átültetése egy ettől nagymértékben eltérő vallásfelfogással, népi hiedelemvilággal rendelkező kultúrába. Szintén e kérdéskör vizsgálatát előlegeztem meg

48 Vö. Ōhashi 1999: 134.

49 Howland 2002: 2. 
Fukuzawa idézett Függetlenségi nyilatkozat-parafrázisával. A Creator ebben megjelenő ten fordítása egyben a Meiji-kori fordítási stratégiák alapesete is, amennyiben - nem összetételröl lévén szó - itt még nem merül fel az imént említett sajátos problémák zöme. A fö kérdés persze itt is adott, s annál nagyobb a jelentősége: valójában melyik 天-ről van szó?

„Mint mondják, »az ég nem teremti egyik embert a másik fölé[rendeltjévé], s nem teremti egyik embert a másik alá[rendeltjévé] «" ${ }^{50}$ - olvassuk Fukuzawánál. A Függetlenségi nyilatkozat itt felidézett mondata az angol eredetiben a következőképpen áll:

We hold these truths to be self-evident, that all men are created equal, that they are endowed by their Creator with certain unalienable rights, that among these are Life, Liberty and the pursuit of Happiness. ${ }^{51}$

A szakasz Fukuzawa teljes Nyilatkozat-fordításában:

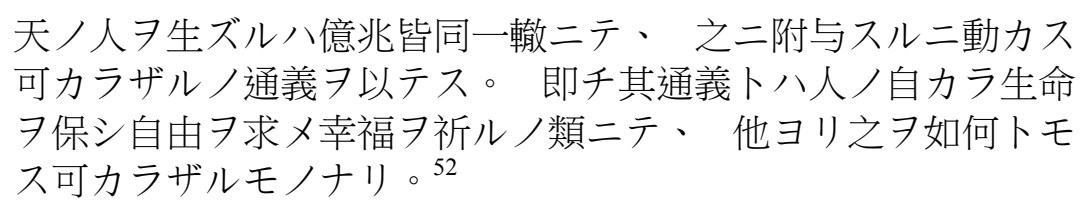

Elkerülendő a többszörös fordítást, megkísérlem a szövegrészt angolra visszaalakítani, tisztában lévén azzal, hogy ez az eljárás „elméletileg és módszertanilag is téves”, mivel a fordítás minden esetben csakis „egyirányú” lehet. ${ }^{53}$ Mégis így lehet talán a leginkább elkerülni, hogy a kulturális különbségek közé saját nyelvi közegünket is bevonjuk harmadikként (vagy épp negyedikként, ha arra gondolunk, hogy az angol nyelv, különösen ebben a szimbolikus jelentőségü szövegben, immár „két kultúrát” képvisel).

As heaven gave life to men, it placed their multitude on the same track, providing them with an unchangeable common righteousness. This common righteousness contains people's maintaining their lives,

50 Fukuzawa 1984a: 51.

51 „The Unanimous Declaration of the Thirteen United States of America.” Lásd Fukuzawa 1991: 37. (A Katō és Maruyama szerkesztette gyüjtemény a Meiji-kori fordítások mellett közli az eredeti szövegeket is, ezeket e kiadásból idézem a fordítók nevével jelölt, a japán fordításéval azonos oldalszámokkal.) A szakaszhoz magyarul lásd Spalding 2011: 109.

52 Fukuzawa 1991: 37.

53 Catford 1965 nyomán Albert 2003: 83. 
their demand of being free, ${ }^{54}$ their seeking well-being; these cannot be taken by anyone from the others in any way. ${ }^{55}$

Hogy a „Teremto”” (Creator) helyén álló ten 天 (,ég”) írásjegy helyét megpróbáljuk meghatározni, meg kell világítanunk a kontextus különböző oldalait. Kezdjük a forrásnyelvével.

Az a doktrína, melyre a Függetlenségi nyilatkozat idézett passzusa hivatkozik, a klasszikus angolszász liberalizmushoz vezet vissza. A természetjog egyik legjelentősebb képviselője, John Locke, aki az amerikai alapító atyák gondolkodására is nagy hatást gyakorolt, úgy határozza meg az emberi együttélés „természetes”, vagyis az állammá szerveződés elötti állapotát, mint amelyben az emberek eleve rendelkeztek bizonyos ,jogokkal”, melyekkel Isten ruházta fel őket. Ennek az a jelentősége, hogy az Isten által az embernek adott jogokat semmilyen földi hatalom (uralkodó, törvényszék stb.) nem veheti el, vagyis az állami keretek közötti együttélésükben az emberek továbbra is rendelkeznek velük. ${ }^{56}$ Mint látható, az elgondolás magjában az emberek eredendő, csorbíthatatlan egyenlösége áll. Azok a felvilágosodás kori gondolkodók, akik e koncepció különböző formáit kidolgozták, az abszolutista uralkodók korszakának végét követelték. Mint Howland - szintén Fukuzawa példáján - rámutat, a Meiji-kori Japán tekintetében ennek az „abszolutizmusnak" a sóguni rendszer felelt meg, ${ }^{57}$ melynek egyik legerősebb ideológiai építőköve a konfuciánus tanítás volt. Ebben az ég mint az uralkodó szülője és az emberek feladatát kirovó legmagasabb irányító erő tölt be központi szerepet.

Az ősi japán hitvilágban az „ég” úgyszólván egy „hely” (lásd takama no hara 高天の原): nincs ,gyermeke” (vö. tianzi/tenshi 天子), nincs útja (vö. tian dao/tendō 天道), és nincs elrendelése sem (vö. tian ming/tenmei 天命). Nemcsak az égnek nincs azonban ilyen szerepe - nincs olyan kami 神 sem, amely hasonló kitüntetettségü volna. Az a 天 tehát, amely Fukuzawa fordításában megjelenik, nem más, mint a klasszikus konfuciánus tanítás

54 A jiyū már a 19. században is a holland vrij (,,szabad”) megfelelőjeként jelenik meg a keresztény kontextusban születő fordításokban (lásd Yanabu 2009a: 180), így itt megtartottam ezt a ,bevett” értelmet.

55

Az utolsó tagmondat, mondja Maruyama, az „,[el]mozdíthatatlan” (ugokasubekarazu 動カス可カラズ) kiegészítéseként, azzal együtt adja az „unalienable” fordítását. (Lásd Maruyama 1991: 409.)

56 Locke 1999: XI. fejezet.

57 Howland 2001: 171. 
„ege" ${ }^{\text {58 }}$ - az az ég, amely az uralkodó egyetlen feljebbvalójaként, az emberek életét meghatározó elrendelés (tianming/tenmei 天命) forrásaként, az égalatti (tianxia/tenka 天下) uraként áll az emberek fölött. Hiába fordul tehát a Tokugawa-kor végén igen jelentős kokugaku 国学 irányzat Kínával szemben Japán felé, ${ }^{59} \mathrm{~s}$ hiába fordul a Meiji-megújulás értelmisége a „feudálisnak" nevezett Tokugawa-korral szemben a Nyugat irányába, a legrégebbi kínai hagyomány rögtön visszatér az egyik központi nyugati eszme fordításában, méghozzá annál a Fukuzawa Yukichinél, aki a konfuciánus hagyomány eltörlésének elszánt sürgetője volt. ${ }^{60} \mathrm{~A}$ konfuciánus tian/ten persze, erős leegyszerüsítésben, mutat bizonyos hasonlóságokat a keresztény Istennel: minden dolog felett hatalommal rendelkezik, egyetlenegy van belöle, és a szó sajátos értelmében ,ugyanott”, mondhatni, ugyanabban a szférában található, mint a kereszténység értelmében vett Isten. ${ }^{61}$ Éppenséggel ezek a jellegzetességei teszik azonban sajátosan konfuciánussá és kifejezetten idegenné a belső keletkezésü japán hitvilágtól, amelyben már a kínai uralkodónak küldött híres 7. századi levél is két égről, a lemenő és a felkelő nap országának egéről beszélt; ${ }^{62}$ amelyben istenségből nem egy van, hanem sok ezer; s amelyben ezek az istenségek a legkülönbözőbb természeti jelenségekben, tárgyakban létezhetnek. E különbségeket mérhették fel a korai jezsuita hittérítők, amikor kínai elődeikkel szemben Japánban nem a 天 „fordítást”, hanem a deuse デウセ átiratot használták, illetve később a kami szót, ${ }^{63}$ részben azért is, mert - persze tévesen - a 神 írásjegyet azonosították kínai „lélek” jelentésével, amelyet a Biblia kínai fordításakor is alkalmaztak. $^{64}$

Annak, hogy a ten fordítás milyen szorosan kötődik a konfuciánus tradícióhoz, érzékletes példáját találjuk Nishimura Shigekinél, aki a „nép erényét” (kokumin dōtoku 国民道徳) a konfuciánus tanítás és a nyugati morál össze-

58 Lásd ehhez Maruyama 1991: 408.

59 Lásd Szabó 2011: 151-153.

60 Lásd ehhez Havens 1970: 4.

${ }^{61}$ Ezek a párhuzamok jelennek meg azokban az esetekben is, amikor a tianhez kötődő különböző kínai szavakat az „Isten” (Deus, God) szavakkal fordítják - vö. Várnai 2011: 56-57.

62 A mondat ebben a formában csak a Sui-dinasztiabeli 隋 Kína feljegyzéseiben maradt fenn, idézi Okamoto 2015: 27.

63 Aruga 1999: 1413.

64 Lásd Yanabu 2001: 121-129. 
kapcsolása révén kívánta megalapozni. ${ }^{65}$ Nishimura egyik, szintén a Meiroku Zasshiban közölt írásában, melynek tárgya a ,jog”, pontosabban a természetes és a pozitív jog közötti különbség magyarázata, nemcsak a ten, hanem a $J \bar{t} t e i$ 上帝 (kínai Shangdi) fordítást is használja a nyugati keresztény istenkoncepció megfelelőjeként.

A természetes jogok [shizen no kenri 自然ノ權理] minden embernek az életéhez [seimei 性命], testéhez, szabadságához [jiyzu 自由] való joga; továbbá a jog ahhoz, amit munkájával létrehozott; ezen kívül a jog a levegö, a víz, a fény közös használatához. Annak oka, hogy ezeket természetes jogoknak nevezzük, az, hogy az ember az égtöl [ten 天] élö testet [seikatsushitaru karada 生活シタル体] kapott eszes élölény [道理アル動物 dōri aru dōbutsu]. Azért hívjuk tehát a felsoroltakat „természetes jogoknak”, mert ahhoz, hogy az ember teljessé tegye ezen égi adományt [tenshi 天賜], feltétlenül e [jogok] birtokában kell lennie. $^{66}$

Nishimura ezután a kenri szó különböző előfordulásait és vonatkozásait vizsgálja, majd a szöveg végén így fogalmaz:

[A] jog írásjegyeinek van egy második használata is, méghozzá az, amikor az erénytan [,etika”] [dōtokugaku 道德學] területén beszélünk jogról [kenri]. A jogra általában használt szó a törvényen [hōritsu 法律] alapszik, az erénytanban használt jog szó [írásjegyek] pedig Jōtei [Shangdi 上帝] akaratán, e két értelemben vett jog eredetileg nem különbözik. Pusztán arról van szó, hogy az erénytanbeli jog tág értelemben magában foglalja a jog olyan [formáit] is, melyekröl törvényi keretben nem beszélünk. ${ }^{67}$

65 Lásd Satō 2003: 182-183.

66 自然ノ權理卜八凡人類夕ル者八其性命卜身体卜自由卜二就テノ權理アリ又 己ガ勞作 ヨ以て造リタル物二付テノ權理アリ又大氣卜水卜光卜 ルノ權理アリ是等习自然ノ權理卜云フ其故八人類ハ天ヨリ生活シタル体习受 ケ又道理アル動物卜為リ居ル者ナリ此天賜习全クセントスルニ八是非卜モ以 上ノ諸權理习己ガ所有卜為サベルフコ得ズ故二之ヨ名ケテ自然ノ權理卜云フ ナリ」(MRZ 42:1-2).

$67 「$ 權理ノ字二ハ又第二ノ用法アリ則チ道德學二テ言フ所ノ權理ナリ尋常ノ權 理/語八法律习依據卜シテ之习定メ道德學ニテ用フル權理/字八上帝ノ意 依據卜シテ之ヨ定メタル者ニシテ其權理トスル處ノ者八固ヨリ異ナルフナシ 
Nishimura mármost nemcsak amellett foglalt állást, hogy a nép etikai neveléséhez szükség van a konfuciánus alapokra is, hanem tanítása e konfuciánus magját is a szigorúan értelmezett klasszikus konfucianizmusra korlátozta. Ezzel összhangban illeti kritikával a ,liberty” fogalmának jiyūként 自由 való fordítását. ,[A]z, amit a nyugatiak szabadságnak [jiyū] neveznek - írja 1900-ban - csak az emberek egymás közötti kölcsönös szabadsága lehet, az éggel és a földdel szemben senki nem lehet szabad" . ${ }^{68}$ Hogy világosan lássuk, mire utal Nishimura, tanításának központi gondolatát szem előtt tartva célszerü a jiyu ekkorra már viszonylag elterjedt, a „freedom”, illetve „liberty” megfelelőjeként hordozott értelme helyett az írásjegyek eredeti, klasszikus kínai (konfuciánus) jelentésére támaszkodunk. Tézise azt jelenti, hogy az emberi cselekvés eredete (由) a többi emberhez viszonyítva az emberben magában (自) van, ugyanakkor az ember e „maga-ságának” eredete a ten. ${ }^{69}$ A nyugati istenkoncepció tennel való megfeleltetése tehát, úgy tünik, akkor válik érthetővé, ha éppenséggel nem a „modern”, hanem a klasszikus konfuciánus égképzetet értjük rajta, amely - a Zhu Xi-hez kötődő neokonfuciánus megközelítéssel szemben, mely ,az égi elrendelést [tenmei 天命] a kozmosz szabályozójaként [uchūron 宇宙論] fogta fel"70 - közel áll az égnél sokkal inkább antropomorf jellegü Shangdi 上帝 képzetéhez. Amennyiben az Isten 天 megfeleltetésre ebben a vonatkozásban, vagyis a konfuciánus tanítás gyökeréhez való visszatérésként tekintünk, a Meiji-kor gondolkodóinak konfucianizmus-interpretációját az Edo-kor középső szakaszában megerősödő ${ }^{71}$ neokonfucianizmus-kritika, így például a ten és a ri Zhu Xi-féle megfeleltetésével leszámoló Ogyū Sorai 荻生徂徠 tanításához ${ }^{72}$ is köthetjük. Söt,

唯道德學ノ權理ハ其包メル所差廣クシテ法律上ニテ言ハザル所ノ權理ヨモ其 中二算入スルフアリ」(MRZ 42: 4).

$68\ulcorner[\ldots]$ 西人ノ所謂自由卜ハ、人類相互間ノ自由二シテ、天地対シテハーモ自 由ナル能ハズ」(Nishimura 1989: 23).

69 A jelentésekhez vö. Karlgren 1996: 1237m (自) és 1079a (由). Fontos ebben a kontextusban az is, hogy mindkét írásjegy állhat „követni” jelentésben is. Természetesen nem állítom, hogy az itt leírt „maga eredete” értelemben álló ziyu/jiyū ne jelenthetne „szabad-ságot” abban az értelemben, hogy valami vagy valaki magától, vagyis nem külső hatásra tesz valamit - ez azonban nem jelent „,politikai” vagy ,jogi” szabadságot. Vö. Nihon shisōshi jiten 2009: 446. Vö. Koyasu 2010: 90, 100.

71 Az általánosan elterjedt nézettel szemben, mely szerint a Song-kori konfucianizmus már az Edo-kor elejétől uralkodó volt, e tanítás csak később válik elsődlegessé, lásd Szabó 2016: 40-44.

72 Lásd Sorai 1973: 235. 
úgymond „tisztán” a konfucianizmus felől közelítve az is elmondható, hogy Sorai klasszikusokhoz való visszatérése sokkal nagyobb ellentmondást hordozott, mint például Nishimuráé, amennyiben a szigorú piramis-hierarchiára épülő korai társadalomképhez a kétpólusú hatalomszerkezetével fémjelzett Tokugawa-korban - méghozzá a bakufu egyik vezető gondolkodójaként kívánt visszatérni. ${ }^{73}$ Annál nagyobb viszont a feszültség aközött, hogy a Meijikori értelmiség az „elmaradott” Japánt úgy igyekezett a nyugati eszmék révén „felvilágosítani”, hogy azokat, mint látható, nemcsak vállaltan a klasszikus konfucianizmusra építő képviselői ágyazták a tradicionális tanítás konceptuális sémáiba, hanem legvehemensebb újítói is. E feszültség megvilágításához fontos kitérnem a Nishimura soraiban szintén megjelenő „ész” és az ezzel összekapcsolódó ,természetjog”, illetve az ezekhez szintén szorosan kötődő „természettörvény” problémájára.

\section{Naturrecht és seihō 性法, natural right és shizen no kenri 自然ノ権理}

Az európai felvilágosodás egyik központi gondolata az ész, a ratio elsőbbsége volt - számunkra itt az a legfontosabb kérdés, mivel szemben. Amikor Arisztotelész a Nikomakhoszi etika I. könyvében az embert zóon logon echónnak, értelemmel bíró élölénynek nevezi, elsősorban arra az alapvető tulajdonságra utal, amely az embert más élőlényektől megkülönbözteti. A logosz - akár „ész” jelentésében, akár a poliszban való lét előfeltételét jelentő „szó”, „beszéd” értelmében - az ember azon tulajdonsága, amely képessé teszi az állati, ösztönkövetö létmódon való felülemelkedésre még akkor is, ha az értelemmel ellentétes mozgások és az értelem folyamatos küzdelemben állnak benne. A felvilágosodás észközpontúsága mármost elsősorban nem erre a megkülönböztetésre fókuszál. A descartes-i cogito ergo sum esetében a hangsúly nem azon van, hogy az ember azáltal van mint ember, hogy gondolkodik, úgyszólván tehát nem a cogito és a sum igéken, hanem az ergón, a következtetésen, vagyis az ész bizonyosságán: azért lehetek biztos benne, hogy én létezem, mert én gondolkodom. Az ész azt teszi lehetővé, hogy a bizonyosság a hit és a vélekedés helyébe lépjen, az ember pedig eszére támaszkodva (is) biztonságban érezze magát.

73 Vö. Takó 2015: 233-237. 
Így van ez azon felvilágosodás kori meggyőződés esetében is, mely szerint vannak bizonyos általános érvényü, az ész által minden autoritás jóváhagyása nélkül belátható törvényszerüségek, melyekkel az ember egy az államok létrejötte elötti, ún. „természeti” állapotban is rendelkezett. A „természettörvény”, illetve az ebből mintegy következő „természetes jogok” e felfogásában a „természet” sajátos jelentést hordoz. A természetes jogok az ember által alkotott jogokkal, illetve törvényekkel szemben határozhatók meg, amennyiben kezdettől, bármiféle ,jogalkotás” megjelenése előtt érvényesek. Ebben az értelemben „természetesek”, s ilyen voltukban láthatók be az ész által. E bizonyosság ugyanakkor egyáltalán nem áll szemben az isteni Teremtés hitével - ellenkezőleg. ${ }^{74}$ „A természeti állapotot”, írja Locke,

természeti törvény kormányozza, amely mindenkit kötelez; és az ész - amely maga ez a törvény - mindenkit, aki csak hozzá fordul, megtanít arra, hogy mivel az emberek valamennyien egyenlők és függetlenek, senki sem károsíthat meg másik embert életében, egészségében, szabadságában ${ }^{75}$ vagy javaiban. Az emberek ugyanis valamennyien egyetlen mindenható és végtelenül bölcs Teremtő alkotásai; valamennyien egyetlen szuverén Úr szolgái, akik az ő rendeletére és az ő dolgában küldettek a világba $[\ldots]^{76}$

Mennyiben különbözik ez a szemléletmód attól, amely Nishimura fenti soraiban megjelenik? A választ ezen a ponton nem annyira Isten és tian/ten, mint inkább nature és shizen 自然 viszonya révén lehet megvilágítani.

Először is el kell tekintenünk attól, hogy a mai japán nyelvben - és a kínaiban is - a 自然 írásjegyek szolgálnak a nature, Natur stb. szavak fordítására, ${ }^{77}$ sőt, kifejezetten arra kell koncentrálnunk, hogy a 然 eredeti jelentésében egyáltalán nem utalt a mai értelemben vett „természetre”. ${ }^{78} \mathrm{~A}$ 然 jelentése „olyannak lenni”/,olyanná tenni”, a 自-é „,saját magától”/,saját magát”. Így például a híres Laozi-passzusban: „人法地、地法天、天法道、道法

\footnotetext{
74 Lásd ehhez Spalding 2011: 28-29.

75 Értsük itt: a többi emberrel szembeni szabadságában, nem alávetett voltában.

76 Locke 1999: 44.

77 Ezen a ponton továbbá ugyanaz a „kölcsönösség” figyelhető meg a fordítási hagyományban, mint a tian - Deus esetében: a 自然 írásjegyek teljesen bevett fordítása a nyugati sinológiában és japanológiában is általánosan „,nature”, „természet”, függetlenül attól, hogy az alapszöveg mikor keletkezett.

78 Vö. Karlgren 1996: 217a.
} 
自然”, ${ }^{79}$,az ember mintaként a földet követi, a föld mintaként az eget követi, az ég mintaként a daót követi, a dao mintaként azt követi, amilyen [a dao] saját magától", s a hangsúly azon van, hogy a dao - szemben a földdel és az éggel - nem valami mást követ. ${ }^{80}$ Persze amennyiben a 自然 a dolgoknak ezt az eredendően meglévő milyenségét jelöli, egy sajátos értelemben megvan benne a ,nature” azon tulajdonsága, hogy szemben áll az emberi behatás révén megváltoztatott dolgokkal. Csakhogy, mint Yanabu rámutat, ez a szembenállás eltér a nature - art/Kunst kettősségtől, amennyiben

az eredeti értelmében vett ,,shizen” szemben áll ugyan a „,mesterségessel" [jin 'iteki 人為的], de nem áll együtt [ryōritsu 両立] vele. Igaz persze, hogy ami „shizen”, az nem mesterséges. Ugyanakkor a nature, miközben szemben áll a mesterséggel mint arttal, Kunsttal, együtt is áll vele. Pontosabban: kiegészítik egymást. A nature világa, miközben szemben áll az art világával, komplementer viszonyban is van vele. ${ }^{81}$

Abban, hogy a természetjogi tanítás ugyanúgy magába foglalja a természeti törvény - vagyis, ahogy Locke fogalmaz, az ész - isteni teremtettségét, ahogyan a nishimurai magyarázatban az ember a tentől kapja „eszes élőlény” voltát, a két megközelítés hasonlít. Miközben azonban a nyugati természetjogi tanításban nem a természetes és az Istentől eredő egysége, hanem a természetes és az emberi - a jog esetében a pozitív jog - szembeállitása kerül középpontba - természetesen azzal a céllal, hogy a kettőt harmonizálják -, a japán értelmezés az eredendő egység felé billenti a hangsúlyt. Afelé az „erénytani" egység felé, amelyre Nishimura szintén utal, és amely abban különbözik a „törvényen [hōritsu] alapuló” jogtól, hogy tágabb kört fog át - nagyobb halmazt, de nem egy másikat. Ezt az egységet, mint azt néhány példán itt bemutatom, ismét erős szálak füzik a klasszikus konfucianizmushoz.

Térjünk vissza először a Függetlenségi nyilatkozat fordításához. Miután Fukuzawa, ahogy láttuk, a „Creator” helyére a klasszikus konfuciánus értelemben vett tent állítja, a ,rights” terminust a tsūgi 通義 összetétellel fordítja

79 Laozi XXV. (Tőkei fordításában a dao „,a természet törvényeit követi”, Launál „,the way [models itself] on that which is naturally so", Weöresnél ugyanakkor - aki Tökei fordításából dolgozott - ,az út önnön rendjét követi”.)

80 A fa 法 „mintául vesz” jelentéséhez lásd alább.

81 「伝来の「自然」は人人為と対立し、両立しない。「自然」であるとは、人 為的でない、ということである。一方、nature は、人為art, Kunst と対立する が両立する。と言うよりも、たがいに補い合つている。nature の世界は、art の世界と、対立しつつ補い合う関係である。」(Yanabu 2009a: 133). 
japánra. Tipikus példája ez az összetétel annak az esetnek, amelyben szinte eldönthetetlen, hogy a két írásjegy külön kezelhető, illetve kezelendö-e. A tongyi 通義 ugyanis a korai kínai szövegekben (a Mengziben, a Xunziben, a Shijiben is) állandósult szerkezetként jelenik meg „mindenüvé kiterjedő/átfogó ${ }^{82}$ méltányosság/szabályszerüség” értelemben, az esetek nagy részében az ,égalatti” összetétellel együtt (tianxia zhi tongyi 天下之通義), majd az általunk vizsgált korban, mint arra maga Fukuzawa is utal, a right ekvivalenseként is megjelenik. Fukuzawa 1870-es Seiyō jijō 西洋事情 (,Nyugati viszonyok") címü munkájában járja körül a problémát, ahol úgy fogalmaz, a right ,eredendő helyességet jelent” (ganrai shōjiki no gi nari 元来正直の 義なり), alátámasztásul pedig a 正 (zheng/sei, „egyenes[ség]/helyes[ség]”) írásjegynek a right megfelelőjeként való használatát említi a kínai fordításokban. ${ }^{83}$ „A rightnak" azonban, folytatja,

van olyan használata is, melyben keresendő törvényszerüséget [motomubeki ri 求む可き理] jelent. Noha a kínai fordításokban használnak olyan írásjegyeket, mint 通義, 達義 [tongyi, dayi „mindenüvé kiterjedő/átfogó méltányosság/szabályszerüség"], ha jobban megnézzük, ezek nagyon nehezen érthetők. Az eredendően keresendő törvényszerüség azt jelenti, hogy [valamire] igényt kell tartanunk [saisokusuru hazu 催促する筈 ${ }^{84}$, továbbá, hogy ha keressük is, olyan dolog, ami [mindenkinek] egyértelmü[en megvan]. Így például azt mondhatjuk, hogy ha valaki nem tölti be magától értetődően [shitō 至当] elvégzendő kötelességét [shokubun 職分], az ő esetében nincs mindenüvé kiterjedő/átfogó méltányosság/szabályszerüség [通義 tongyi/tsūgi]. Hiszen ha nem végzi el, amit neki magának el kell végeznie, nem fordulhat követeléssel [saisokusuru hazu wa nashi 催促する筈はなし] máshoz sem. ${ }^{85}$

82 A tong 通 jelentéséhez vö. Karlgren 1996: 1185r-S.

83 Megjegyzendő, hogy az itt ,jelent”-ként fordított „....no gi nari” szerkezetben ugyanaz az írásjegy áll ( $g i$ 義), amelyet a tsūgi összetételben a fentiekben „méltányosságként” adtam vissza. Az írásjegy két értelme között láthatóan szoros a kapcsolat, amennyiben a „jelentés” nem más, mint az ,igaz [helyes, méltányos] értelem”. Lásd Karlgren 1996: 2r.: ,igaz, igazságos” (righteous, righteousness), illetve ,igaz értelem, jelentés” (true sense, meaning).

84 A „kell”-ként fordított hazu a korban szintén a right megfelelöjeként volt használatos, vö. Yanabu 2009a: 155-158.

85 「ライトは求む可き理と云了義に用ることあり。漢訳に通義、達義等の字 を用ひたれども、詳に解し難し。元来求む可き理とは、催促する筈、又は求 
Látható egyfelöl, hogy a gondolatmenet egészét tekintve a klasszikus konfuciánus értelemben vett „kölcsönösség” ( $s h u$ 恕) elvére építve határozza meg a ,jog[osság]" egy aspektusát: azt, mely szerint mindenki csak akkor tarthat igényt arra, ami „megilleti”, ha a megfelelő módon illeszkedik abba a rendbe - az égalatti hierarchikus rendjébe -, amely szerint őt egyáltalán bármi megilletheti. ${ }^{86}$ Éppen azért viszont, másfelől, mert ez az értelmezés ismét csak a klasszikus szemléletmódhoz vezet vissza, hiba volna, ha mai nyelvhasználatunknak megfelelően a - valóban igen körülményes - „[...] számára nincs mindenüvé kiterjedő/átfogó méltányosság/szabályszerüség [tsūgi] sem" megfogalmazás helyett csak annyit mondanánk, „elveszti jogait”. Ha ugyanis egyértelmü volna, hogy a 通義, ,jogot” jelöl, az egész magyarázatnak nem volna értelme. Ez a szó viszont nem ezt jelenti. Fukuzawa keresi a módot, ahogyan a right lefordítható - úgy keresi, hogy megpróbálja körülírni, mit jelent, ebben a körülírásban pedig a 通義, illetve 達義 kínai összetételek is segítségére vannak, olyannyira, hogy a Függetlenségi nyilatkozat fordításában maga is az előbbit használja. Márpedig a „keresendő/követelhető törvényszerüség” értelemben vett $t s \overline{u g} i$ nyilvánvalóan nem a megszilárdult összetétel ma is élő, köznapi jelentésére utal (,általánosan ésszerü” ${ }^{27}$ ) - amit már önmagában az is mutat, hogy Fukuzawa a 義 írásjegy két különböző, hasonló jelentésű előtaggal való összetételét említi példaként (通義, 達義) -, hanem a klasszikus konfuciánus értelemben vett „,méltányosságra”. Ennek megfelelően célszerü tehát a tsūgit olvasnunk - és fordítanunk - a korábban idézett helyen, észben tartva eközben, hogy a kiindulópont az ember ten általi „teremtettsége" volt.

A konfuciánus értelemben vett általános érvényüség kapcsán érdemes megemlíteni a Függetlenségi nyilatkozat már idézett fordításának két másik helyét is, melyeken Fukuzawa a „Laws of Nature and Nature's God” kifejezéspárt a butsuri tendō no shizen 物理天道/自然 összetétellel adja vissza

めても当然のことと云ふ義なり。例へば至当の職分なくして求む可きの通義 なしと云ふ語あり。即ち己が身に為す可き事をば為さずして他人へ向ひ求め 催促する筈はなしと云ふ義なり」Idézi Yanabu 2009a: 153.

${ }^{86}$ Vö. Lunyu V/11. A kölcsönösség, írja Kósa, ,,a hierarchia különböző fokán állók számára nyújt normatív útmutatást azáltal, hogy felhívja a figyelmet annak végiggondolására, hogy vajon mit várna el az illető akkor, ha a másik személlyel pozícióik felcserélődnének” (Kósa 2013: 56). A „kölcsönösség” értelmezéséhez az európai Kínarecepcióban lásd Takó 2014: 404.

87 Howland (2002: 127) szintén külön jelentésükben kezelendö írásjegyekként kezeli a tsūgi írásjegyeit. 
- így lesz a természet törvényeiből és a természet istenéből „a dolgok rendjének és az ég útjának milyensége [»természete«] ${ }^{\text {" }} 88$-, a „with a firm reliance on the protection of Divine Providence" mondatrészt pedig ,tendō no fujo wo kataku shinjite”-ként 天道/扶助 7 固ク信ジテ fordítja, ami által „,az isteni előrelátás védelmébe vetett szilárd bizodalomból”, ${ }^{19}$ „az ég útjának segítségében való szilárd bizodalomhoz" jutunk. Igaz, egyfelől úgy tünik, a tendō összetétel nem kötödik annyira közvetlenül a klasszikus konfuciánus értelemben vett tian daójához, mint inkább a korai Tokugawa-kori tendō-képzethez, amelyet a nyugati szakirodalomban gyakran tendō-hitnek is neveznek (amely ugyanakkor nem kevésbé ellentmondásos választás, amenynyiben az említett időszakban épp a Tokugawa uralmat tekintették a tendō megtestesülésének, ${ }^{90}$ vagyis azt, melynek helyén a Meiji-korban a császár uralmát „állították helyre”); másfelől viszont ismét nyitott kérdés, állandósult összetételként kell-e olvasnunk a tendōt ezen a helyen, vagy még inkább: eldönthető-e egyáltalán, mennyiben kezelendő a két írásjegy „együtt” vagy „külön”.

A shizen és a nyugati „természet”-fogalom, illetve az ebből eredő ,jogok” és japán „megfelelöik” aszimmetriájának másik jellegzetes esete Katō Hiroyuki 加藤弘之 (1836-1916) Johann Caspar von Bluntschli Allgemeines Staatrechtjéből (1852) készített fordítása, melyben Katō rövid magyarázatokat is füz az egyes terminusokhoz. Amikor mármost Bluntschlinál megjelenik a „Natur- oder Vernunftrecht" (,természet- vagy észjog”) fogalompár, ${ }^{91}$ Katōnál a „seihō (natsūrurefuto) sunahachi ryōchihō (herununfutorefuto)" fordítást találjuk, a következő magyarázattal: „,nem korunkban hozott törvény, hanem a természeti ember égtől kapott ${ }^{92}$ törvénye". ${ }^{93}$ Tanúi vagyunk itt, először is, hogy a magyarázatban a „természet” mint a korai - nem a pozitív jog közegében élő -, „természeti” ember kvázi jelzőjeként jelenik meg. Ebben is tükröződik, hogy a shizen még csak ekkor kezd a „nature” főnévi alak-

88 Fukuzawa 1991: 37, 42 .

89 Az angol szöveg magyar fordítását módosítottam.

90 Lásd Ooms 1997: 46-47.

91 A gondolatmenet egészét itt nincs módom bemutatni. Bluntschli amellett érvel, hogy a tudományos jogalkotás a nép jóváhagyásában, vagyis a természeti, illetve „észjogból" levezetett meggyőződésben gyökerezik.

92 A tenpu a mai nyelvben az angol „natural”, ,inborn” megfelelőjeként használatos.

$93\ulcorner$ 性法〈ナツールレフト〉即チ良知法〈へルヌンフトレフト〉\{現二定立セ ル法ニハアラズ、自然人ノ天賦二具備スル法ナリ $\}\lrcorner($ Katō 1991: 69). 
jának megfelelőjévé válni korábbi használatával szemben. ${ }^{94}$ Látható továbbá, másodszor, hogy a Naturrecht - seihō 性法 megfeleltetésben - mint Howland hasonló példákon rámutat ${ }^{95}$ - megjelenik az emberben kezdettől fogva meglévő, az égtől származó beállítódás, az élet „szabálya”, „mintája”, „törvénye” értelmében vett konfuciánus eredetü xing/sei 性 terminus, amely azonban nem a legkorábbi tanításhoz, hanem a Mengzi 孟子 szemléletmódjához kötődik. ${ }^{96}$ Harmadszor, ugyanebben az összetételben látjuk azt is, ahogyan a „Recht” (,jog”) „törvény[szerüség]ként” ( $h \bar{o}$ 法) jelenik meg, ami ismét a konfuciánus alapokat idézi. A $f a / h o ̄$ ugyanis csak egészen későn nyeri el „pozitív törvény”, ,jogszabály” értelmét, ${ }^{97}$ amellyel azonban a fordításban megjelenő sei, vagyis az ember égtől kapott „,beállítódása” igen bajosan volna összeilleszthető. Úgy tünik tehát, hogy itt az írásjegy korai, „minta”, „mintául vesz” értelmében áll, s ezzel a konfuciánus hagyományhoz kapcsolódik, melyben pedig azt a szembenállást, melyet „mi lex és ius között oly döntö különbségnek tartunk [...] szinte nem is »érzékelték «." ${ }^{98} \mathrm{E}$ gondolkodásmód egyik jellegzetes származéka a Katō által gyakran használt, a fent idézett szakaszban is megjelenő tenpu jinken 天賦人権 (,,az ember égtől kapott joga”), melyet a szakirodalomban gyakran a „,natural right” megfelelőjeként kezelnek, de amelynek példáján Wakabayashi épp az általam is vizsgált jelenséget szemlélteti. „Amikor Katō", írja Wakabayashi,

és más 19. század közepi japán gondolkodók nyugati filozófiai fogalmakat fordítottak le, a klasszikus kínai szövegekben található írásjegyösszetételeket használtak, vagy a klasszikus kínai stílus [diction] mintájára dolgoztak ki újításokat. A japán gondolkodók így akarattalanul vehettek át hallgatólagos feltevéseket és mentális asszociációkat a konfuciánus hagyományból. Ezáltal a japán képzet [conception] különbözött a nyugati fogalomtól [concept]: egy olyan terminus, mint a tenpu jinken, az eredeti nyugati gondolattól eltérő konnotációkat vett fel. Röviden, sokkal kisebb mértékben történt radikális szakítás a konfuciánus intellektuális hagyománnyal, mint azt hajlamosak vagyunk hinni. ${ }^{99}$

\footnotetext{
94 Yanabu 2009a: 135, 137-138.

95 Lásd pl. Howland 2002: 64-65.

96 Vö. Kósa 2013: 69.

97 Lásd Várnai 1984: 101, Salát 2016: 44.

98 Várnai 1984: 102.

99 Wakabayashi 1984: 491.
} 
E folyamat - „átvitel” - példája Nishimura kifejezése, a shizen no kenri 自然ノ權理 második eleme, a „right” értelemben álló kenri, melyhez végül vissza kell térnünk. Az ebben található - a ma is használt kenri 権利 (,jog”) összetétel első tagjával azonos ${ }^{100}$ - 権 (權) írásjegy szintén a Meiji-korban kerül használatba mint a holland regt megfelelője, $\mathrm{s}$ érdekes módon végül ez szorítja majd háttérbe számos riválisát, holott eredeti jelentése nem áll éppen közel forrásnyelvi párjához. A 權 írásjegy eredetileg „súlyt”, ,mértéket” jelentett, átvitt értelemben valaki „súlyát”, vagyis „hatalmát”, ,jog”-ot egyáltalán nem. ${ }^{101}$

Yanabu Nishi Amane Bankoku kōhō 万国公法 címü 1868-as, Simon Vissering (1818-1888) előadásaiból készült fordítását vizsgálva úgy érvel, a holland regt kenként való értelmezése - minthogy a ken konnotációival a kangakun (klasszikus kínai tanulmányokon) nevelkedett Nishi nyilvánvalóan tisztában volt ${ }^{102}$ - abból a „nem is annyira természetellenes félreértésből”,103 ered, hogy úgy vélte, mivel az országok ${ }^{104}$ egymással szembeni jogai (regt) az országok „hatalmából” erednek, a regt végső soron megfeleltethető a hatalomnak. Ez az átértelmezés persze, tehetjük hozzá, már nem a holland jogtudomány, hanem épp a sinocentrikus kultúrkör „természetével” van összhangban, amennyiben a ,jog” "súlyként” (még szemléletesebben: az egyenlö jogok egyenlö súlyként) való értelmezése e hagyomány felöl valóban kézenfekvőnek tünhetett. Hasonlóképp, azt, hogy Nishimura a „természetes”, vagyis az égtől mint Shangditól származó jogokat shizen no kenrinek 自然ノ權理 nevezi, sokkal világosabban értjük, ha a kenrit az emberek ,súlyának/mértékének rendjeként" olvassuk - ebben a tekintetben lehetnek az emberek eszük révén egyenlők egymással. Ezzel összhangban az a mód, ahogyan Nishimura az embert mint „eszes élőlényt” (道理アル動物) leírja, sokban emlékeztet arra, ahogyan Matteo Ricci, platóni-arisztotelészi felhangokat vegyítve keresztény katekizmusokra emlékeztető érvelésébe, az „észként”

100 A 権利 alak szintén használatos volt már a korban, megtaláljuk például Katō Hiroyuki említett fordításában is (lásd pl. Katō 1991: 84; ahol a németben a „Recht” szó nem is szerepel, a „Freiheit und Gleichheit" lesz ,jiyz [...] oyobi dōtō [...] no kenri" $\ulcorner$ 自由 $[\ldots]$ 及ビ同等 $[\ldots]$ / 権利」).

101 Howland (2002: 123) úgy érvel, hogy a ken írásjegye által kifejezett „hatalom” az „ítélés” értelmében vett „mérlegelésen” alapul.

102 Yanabu 2009a: 162.

103 Yanabu 2009a: 165.

104 Itt a Nishi hollandiai tanulmányainak is tárgyát képező nemzetközi jogról van szó. 
értelmezett lit 理 mint az ember fő megkülönböztető jegyét állította középpontba. ${ }^{105}$

Mindez persze nem jelenti, mint Yanabu rámutat, hogy a ken „tulajdonjog” (shoyu no ken 所有ノ権) és „végrehajtó hatalom” (gyōseiken 行政権) értelemben való használata között ne lett volna különbség - „látnunk kell azonban $[\ldots]$ hogy a hasonló megkülönböztetések nem voltak tudatosak. Legalábbis nem tudatosultak teljes mértékben." ${ }^{106}$ Yanabu arra is érzékletesen mutat rá, hogy a fordítást a már létező kínai fordítások, illetve a nyugati nyelvek hasonló, de nem teljesen azonos jelentésủ terminusai közötti diszkrepanciák is befolyásolták. William Martin, egyfelöl, szintén a quan 權 írásjegyet alkalmazta a regt megfelelöjeként Henry Wheaton Elements of International Law címü mủvének (1836) kínai fordításában, terminológiája pedig Nishire egyértelmủen hatással volt. ${ }^{107}$ Másfelöl a holland regt terminus az angol „,right”-tal szemben - az etimológiai kapcsolat ellenére - ,[pozitív] törvény” (hōritsu 法律) jelentést is hordoz, ${ }^{108}$ ami - a rangaku hatásán keresztül is erősítette a jog-törvény megfeleltetést és a Vissering által is képviselt jogpozitivista értelmezésmódot, amellyel a ken írásjegyében megjelenő joghatalom összekapcsolás természetesen ellentétbe kerül. A ken e használata, tehetjük hozzá végül, ezáltal többszörösen ellentmondásos viszonyban van a right megfelelőjeként Fukuzawa által alkalmazott givel, mely terminus úgyszólván a mai napig megtartotta általános vonatkozását, sőt, mint a tsūgi példája is mutatja, tovább általánosodott, így közelebb áll a nyugati értelemben vett „természetes jogok” hagyományához, miközben a kenhez hasonlóan

105 Ricci 2004: 233-234. Ricci, amikor a lire támaszkodott, kevéssé láthatta át a Song-kori konfucianizmus szerepét a tanítás átalakításában, de kétségtelen, hogy a li azon jelentőségét, amelyet felismert, elsősorban Zhu Xi tanítása adta. A párhuzam kapcsán ezért is fontos, hogy a dōri már évszázadokkal a Song-kori konfucianizmus kialakulása előtt megtalálható volt Japánban, az összetétel először a Shokunihongiban 続日本紀 fordul elö (VIII. sz. vége), lásd Nihon shisōshi jiten 2009: 713.

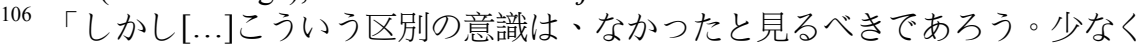
とも、はつきり意識されてはいなかつたのだ[...]。」(Yanabu 2009a: 166).

107 Yanabu 2009a: 163. Wheaton Martin-féle fordítása 1865-ben, a három évvel később kiadott Nishi-féle Vissering-fordításhoz hasonlóan Bankoku kōhō címen jelenik meg Japánban, ehhez lásd Howland 2002: 124-125.

108 Yanabu 2009a: 155-156, Howland 2002: 123. Nishi a volkenregt („nép[ek közötti]jog”, ma „nemzetközi jog”) terminus definícióját tartalmazó mondatban például e terminust bankokuhōként 万国法, a regtswetenschap (,jogtudomány”) terminust hōgakuként 法学 (szó szerint „törvény-tudomány”), de ugyanebben a mondatban a regtet önmagában már kenként fordítja. Lásd Yanabu 2009a: 164. 
sajátos, a klasszikus kínai hagyományt idéző konnotációkat is hordoz. 権 és 義 ilyen, a mai szóhasználatra is hatást gyakorló különbsége ezáltal érzékletes példájává válik annak is, milyen szövevényes úton nyerik el jelentésüket a hétköznapi nyelvhasználó számára magától értetődő módon használt kifejezések.

\section{Az új vagy ,az ujj”?}

Az olvasóban talán már az eddigiek nyomán is felmerült a kétely: hogyan lehetnénk biztosak abban, hogy az itt említett írásjegyeket valóban úgy értették? Nem lehetséges, hogy a 天 egyszerüen csak egy írásjegy volt, amelyről tudták, hogy mikor mire utal, s használata valójában nem kötötte össze a nyugati müveket fordításaikon keresztül a konfuciánus hagyománnyal? A válaszhoz a fordítás folyamatába kell megpróbálnunk beleképzelni magunkat. Az ilyen kérdésfeltevés ugyanis azt az elképzelést implikálja, hogy a fordítók világosan látták a különbséget a nyugati és a kelet-ázsiai hagyományok egyes elemei között, de úgymond ,jobb híján” beérték például a 天 írásjeggyel a „Deus”, „God” megfelelöjeként. Ha azonban így van, miért használta maga Fukuzawa is későbbi szövegeiben a ten helyett a Zōbutsushu 造物主 (,a dolgokat létrehozó úr") összetételt? ${ }^{109}$ Vagy, ha egyszer Katō saját magyarázatában használta a shizen írásjegypárt a természeti állapot leírására, miért fordította a Naturrechtet mégis seihōként a későbbi shizenhō 自然法 helyett? Vajon lehetséges-e, hogy valaki - és ne feledjük, az itt említett gondolkodók az 1860-as évek második felében nem tanulmányaik elején jártak, hanem zömmel 30-as, 40-es éveikben - több évtizedes tanulmányainak egy igen jelentős részét tudatosan mintegy „lezárja”, hogy belehelyezkedjék egy másik, évezredek hagyománya során kialakult gondolkodásmódba? Nem helyesebb-e úgy közelítenünk a fenti kérdésben megfogalmazott problémához, hogy a Meiji-kor gondolkodóinak fordításaiban, noha természetesen érzékelték a különbséget például a God és a 天 terminusok között, mégis annak a folyamatnak lehetünk tanúi, melynek során saját magukban tudatosították, miben is állnak valójában ezek a különbségek? Miközben fokról fokra eltávolodtak a hagyománytól, mondhatni, saját magukat is „átvitték” (,trans-ferre”) valami

109 Lásd ehhez Craig 2009: 65-67. A 主 írásjegyet használta Matteo Ricci is, lásd Ricci 2004. 
másba - de, mint Wakabayashi, Yanabu, Ōhashi is rámutatnak, korántsem „hagytak hátra” mindent abból, amit addigi pályájuk során elsajátítottak.

A fenti elemzés felhívja a figyelmünket arra, mennyire óvatosan kell kezelnünk azokat a látszólag egyértelmü utalásokat, amelyeket a Meiji-kori szerzők például a 自由-ra és a 天-re - azaz (?) a „szabadságra” vagy „Istenre” - tettek. Ez ugyanakkor nem jelenti, hogy a megfeleltetések helyett ellentéteket feltételezve a probléma megoldódik. Creator és natural right, illetve ten és $g i$ jelentéshálóján ez jól szemléltethető. Elmondható ugyanis, először, hogy a konfuciánus értelemben vett ég hasonlóképp „,ad" valamit az embernek, mint a nyugati-keresztény értelemben vett teremtö Isten. $A z$ azonban, amit ad, másodszor, éppenséggel az embernek a társadalmi hierarchiában elfoglalt helye, az alá-fölérendeltségi relációk hálójában számára kijelölt csomópont, nem pedig az őt mindenkivel egyenlővé tevő „természetes jogok” összessége. Csakhogy, harmadszor, ez az egyenlőség vs. egyenlőtlenség szembeállitás is torzít, ha úgy értelmezzük, hogy a kínai társadalom a nyugati felvilágosodás kori egyenlőség-fogalom ellentéte értelmében „,egyenlőtlen” volt. Ebben az értelemben ugyanis nem volt az, amennyiben bár alá-fölérendeltségi viszonyok határozták meg, az ezekben helyet foglalók nagyon is „egyenlők” abban az értelemben, hogy miközben mind rendelkeztek az alattuk állók feletti hatalommal, az ezt biztosító szemléletmódnak legalább ennyire szerves alkotóeleme volt az irántuk tanúsított felelősség és törődés, így egyenlők voltak abban, hogy mindenki fölött egyaránt állt valaki, s minél kevesebben voltak ezek, annál nagyobb hatalommal rendelkeztek - egészen az ég fiáig, aki felett maga az ég állt. Éppen azért mármost, mert e struktúra gyökerét ez az „egyenlőség”, illetve ennek szigorú, ám rendkívül stabil múködőképessége jelentette, a „modernizáció” Nyugat felé fordulása sem tudta ezt a konfuciánus értelemben vett egyenlöséget a nyugati értelemben vett egyenlőtlenségként feltüntetni, s így nem tudta a nyugati egyenlöség-fogalommal felváltani sem. Ez az aszimmetrikus viszony rejlik a korábban tárgyalt, Meiji restauráció - Meiji forradalom kettősség mögött.

Fontos ugyanakkor, hogy a bemutatott jelenség egyáltalán nem újkeletü. A hagyományok egybefonásának mesteri szinten müködtetett technikája ugyanúgy funkcionál a Meiji-kor nyugatiasságában, ahogyan a konfucianizmus, a buddhizmus és a shintō egybeforrt Shōtoku taishi 聖徳太子 Tizenhét cikkelyes alkotmányában (604), ahogyan a shintō és buddhista istenségek eggyé olvadtak a honji suijaku 本地垂迹 elméletben, vagy ahogyan Ogyū Sorai a konfuciánus klasszikusok tanulmányozására szólított fel a Song- 
kori, torzult értelmezést kritizálva, de vonatkozó írásaiban a kínai hatalomszerkezettel esszenciálisan ellentétes sóguni kormányzatot is legitimálta. ${ }^{110}$ Fung Yu-lan A kínai filozófia rövid történetében írja le a régi kínai elbeszélést, mely szerint

egy ember összetalálkozik egy halhatatlannal, aki megkérdezi a halandótól, mi a kívánsága. Az ember aranyat akar. A halhatatlan ekkor ujjával megérint néhány követ, amelyek egy szempillantás alatt arannyá változnak. A halhatatlan az embernek adná az aranyat, ám az nem fogadja el. „Mi mást akarsz hát?” - kérdezi tőle a halhatatlan. „Az ujjadat!" - feleli a halandó. ${ }^{111}$

Az analógia lényege, ahogyan Fung használja, hogy nem az eredmények, hanem a módszer az, amire a kínai gondolkodásnak a nyugatiból szüksége volt. Ami mármost a módszert illeti, mint tudjuk, Japán is összegyüjtötte mindazt, amire a Nyugat filozófiai, államszerkezettani, tudományos készletéből igényt tartott. Az „ujjat” tehát Kínához hasonlóan Japán is igyekezett megszerezni - gondoljunk például a Fung által Kína vonatkozásában is kiemelt logikatudomány átemelésére, melynek egyik központi alakja Japánban az említett Nishi Amane volt. ${ }^{112}$ Ezt az ujjat azonban igen körültekintően és rendkívül mérsékelten használták arra, hogy valami újat hozzanak létre, mégpedig nem a régi helyén vagy annak romjain. Karl Löwith, az 1936 és 1941 között Japánban élő német filozófus úgy fogalmaz, Japánban a modernizáció óta két „emeleten” folyt az élet: ,a földszinten teljesen japán módra, az emeleten félig nyugatiasan". ${ }^{113}$ Löwith a lépcsőt hiányolja, tévesen - tette hozzá egyik előadásában Ōhashi. A japánok ugyanis, folytatja, nem új szintet építettek, hanem „házuk” egyik szobáját alakították át, így kaptak yōmát 洋間 („nyugati [típusú/stílusú] szoba”) a washitsu 和室 (,japán [stílusú] szoba”) mellett, a kettőt pedig nem a jellegzetesen zárt nyugati típusú ajtó, hanem a hagyományosan nyitva hagyott shōji 障子 választotta el. ${ }^{114}$ Igaz, Nishi és kortársai meghonosították a Nyugattól tanult módszereket, így például a logikai elemzést - ennek terminusai között azonban nemcsak olyan „semleges” elemeket találunk, mint kōtei 肯定 és hitei 否定 (,affirmáció” és „,ne-

\footnotetext{
110 Lásd Takó 2015: 249

111 Fung 2003: 395.

112 Nishi Amane logikai(-fordítói) munkásságához lásd Havens 1970: 98-102.

113 Löwith 2013: 56.

114 Ōhashi 2014.
} 
gáció”), hanem olyanokat is, mint az „,a priorinak” („tapasztalattól függetlenül, önmagában megismerhető") megfelelő senten 先天 és az „a posteriori" („tapasztalati úton megismerhető") megfelelőjeként álló kōten 後天. ${ }^{115}$ Természetesen nem azt állítom, hogy Nishi logikája ezáltal „konfuciánus logikává” vál(hatot)t volna. Csakis arra hívom fel a figyelmet, hogy ez az i. e. I. ezred első felére datálható Yijingben 易經 (Változások könyve) és az i. sz. 19. század végi, nyugati szövegekből készülő logikai fordításokban egyaránt megjelenő írásjegypár jól tükrözi a japán eszmetörténet egy korról korra megjelenő sajátosságát, amely a Meiji-megújulást is áthatja: a külső elemek belső elemekkel és ezzel párhuzamosan egymással való ötvözésére való rendkívüli képességet, egyben hajlamot. Ezzel a technikával emeltek „hidat” a Meiji éra gondolkodói a Nyugat és Japán közé, méghozzá olyan sietve, hogy a túlsó parton már súlyos szállítmányok indultak át rajta, miközben az innensőn még el sem érte a partot, eközben viszont a híd mégis igen megbízható volt: erős, évezredes cölöpök tartották, méghozzá faragott fából.

\section{Elsődleges források}

Fukuzawa Yukichi 福沢諭吉 1984a. „Gakumon no susume「学問のすすめ」[A tudomány előremozdítása].” In: Nagai Michio 永井道雄 (ed.) Fukuzawa Yukichi. (Nihon no meicho 日本の名著 33.). Tōkyō: Chūōkōron, 49-146.

Fukuzawa Yukichi 福沢諭吉 1984b. „Bunmeiron no gairyaku「文明論の概略」[A civilizációelmélet kivonata].” In: Nagai Michio 永井道雄 (ed.) Fukuzawa Yukichi. (Nihon no meicho 日本の名著 33.). Tōkyō: Chūōkōron, 147-232.

Fukuzawa Yukichi 福沢諭吉 (ford.) 1991. Amerika dokuritsu sengen アメリカ独立宣言 [Amerikai függetlenségi nyilatkozat] [The Unanimous Declaration of the Thirteen United States of America]. In: Katō Shūichi 加藤周一 / Maruyama Masao 丸山真男 (eds.) Hon'yaku no shisō 翻訳の思想 [A forditás az eszmetörténetben] (Nihon Kindai Shisō Taikei 日本近代思想体系 15.) Tōkyō: Iwanami Shoten, 37-42.

Katō Hiroyuki 加藤弘之 (ford.) 1991. Kokuhō hanron 国法汎論 [Az államjog alapjai] [Johann Caspar von Bluntschli: Allgemeines Staatrecht]. In: Katō Shūichi加藤周一 / Maruyama Masao 丸山真男 (eds.) Hon'yaku no shisō 翻訳の思想 [A fordítás az eszmetörténetben] (Nihon Kindai Shisō Taikei 日本近代思想体系15.) Tōkyō: Iwanami Shoten, 43-90.

[Laozi - Dao de jing 道德經] Tao Te Ching 2001. [Trans. D.C. Lau] Hong Kong: The Chinese University Press. (kínai-angol kétnyelvü kiadás) Magyarul: „Laozi (Daode-

115 Lásd Yamakawa 1994: 35. A két írásjegypár a Változások könyvében „,az eget megelőzve” és ,,az eget követve” értelemben, a „nagy ember” (daren 大人) vonatkozásában fordul elö. Lásd Yijing 1996: 133. (I/23). 
jing).” In: Tőkei Ferenc (ford., vál., jegyz.) 2005. Kínai filozófia. Ókor. II. kötet. Budapest: Magiszter Társadalomtudományi Alapítvány, 17-50. Weöres Sándor verses fordítása: Lao-ce 2001. Tao Te King. Gyula: Tericum.

Locke, John 1999. Második értekezés a polgári kormányzatról. [Ford. Endreffy Zoltán] Kolozsvár: Polis.

[Lunyu 論語] Confucius 2002. The Analects. [Trans. D.C. Lau] Hong Kong: The Chinese University Press. (kínai-angol kétnyelvü kiadás) Magyarul: „Beszélgetések és mondások.” In: Tőkei Ferenc (ford., vál., jegyz.) 2005. Kínai filozófia. Ókor. I. kötet. Budapest: Magiszter Társadalomtudományi Alapítvány, 57-177.

MRZ: Meiroku Zasshi 明六雑誌 [Meiji Hat Folyóirat], 1-43. szám (1874-1875). Elérhető a Nihongoshi Kenkyū Shiryō 日本語史研究資料 [Japán nyelvtörténetkutatási források] adatbázisban: http://dglb01.ninjal.ac.jp/ninjaldl/bunken.php?title =meirokuzassi [Utoljára megtekintve: 2017.12.17.]. Angolul: W. R. Braisted (trans.) 1976. Meiroku Zasshi. Journal of the Japanese Enlightenment. Cambridge, Mass.: Harvard University Press.

Nishi Amane 西周 [1874],YYoji wo motte kokugo wo shosuru no ron「洋字习以て國 語习書スルノ論」[Esszé a japán nyelv nyugati írásjegyekkel való lejegyzéséről]." MRZ 1: 1-10.

Nishi Amane 西周 [1874] „Hi Gakushashokubunron「非學者職分論 」[»A tudomány müvelőinek feladatáról szóló esszé« kritikája].” MRZ 2: 4-6.

Nishimura Shigeki 西村茂樹 [1874] „Kaika no tabi ni yorite kaimoji wo hassubeki no ron 「開化ノ度二因テ改文字习發スへキ/論」[Esszé az írás megújításának szükségéről a felvilágosodásban].” $M R Z$ 1: 10-12.

Nishimura Shigeki 西村茂樹 [1875] „Kenrikai 「權理解」 [A jog magyarázata].” MRZ 42: 1-4.

Nishimura Shigeki 1989. „Jishikiroku 自識録 [Feljegyzések az öntudatról] [részlet].” In: Senuma Shigeki 瀬沼茂樹 (ed.) Meiji tetsugaku shisōshū 明治哲學思想集 [A Meiji-kori filozófiai gondolkodás gyüjteménye]. Tōkyō: Chikuma Shobō, 18-24.

Ogyū Sorai 荻生徂徠 1973. „Benmei” 辨名 [A nevek megkülönböztetése].” In: Yoshikawa Kōjirō 吉川幸次郎 et. al. (eds.) Ogyū Sorai 荻生徂徠. (Nihon shisō taikei 日本思想大系 36.) Tōkyō: Iwanami Shoten, 209-255.

Ricci, Matteo 2004. Tenshu jigi [Tianshu zhiyi] 天主実義 [Az ég urának valódi jelentése]. Tōkyō: Tōyō Bunko.

[Yijing 易經] Imai Usaburō 今井宇三郎 (ed.) 1996. Ekikyō 易経 [Változások könyve]. (Shinshaku kanbun taikei 新釈漢文大系 23/1.) Tōkyō: Meiji Shoin. (A kínai szöveg japán mellékjelekkel ellátott kiadása.)

\section{Másodlagos szakirodalom}

Albert Sándor 2003. Forditás és filozófia. A forditáselméletek tudományfilozófiai problémái - Filozófiai szövegek forditási kérdései. Budapest: Tinta. 
Aruga, Tadashi 1999. „The Declaration of Independence in Japan: Translation and Transplantation, 1854-1997." The Journal of American History 85/4: 1409-1431.

Braisted, William R. 1976. „Introduction.” In: W.R. Braisted (transl., intr.) Meiroku Zasshi. Journal of the Japanese Enlightenment. Cambridge, Mass.: Harvard University Press, xvii-xlviii.

Brancaccio, Lavinia 2007. China accomodata. Chinakonstruktionen in jesuitischen Schriften der Frühen Neuzeit. Berlin: Frank \& Timme.

Clements, Rebekah 2015. A Cultural History of Translation in Early Modern Japan. Cambridge: Cambridge University Press.

Craig, Albert M. 2009. Civilization and Enlightenment. The Early Thought of Fukuzawa Yukichi. Cambridge, Mass. / London: Harvard University Press.

Eisenstadt, S.N. 1996. Japanese Civilization. A Comparative View. Chicago and London: University of Chicago Press.

Facius, Michael 2012. „Japanisch - Kundoku - Chinesisch. Zur Geschichte von Sprache und Übersetzung in Japan.” Geschichte und Gesellschaft 38/2: 217-242.

Farkas Ildikó 2012. „Kitalált, felújított vagy valódi hagyományok? Gondolatok a japán modernizáció kérdésköréhez." Távol-keleti Tanulmányok 2012/1-2: 79-98.

Farkas Ildikó 2016. „Modernizáció tradícióval - A japán példa.” In: Salát Gergely Szilágyi Zsolt (szerk.) Kulturális hagyomány a modern Kelet-ázsiai államban. Budapest: L'Harmattan, 213-229.

Fält, Olavi 2005. „The Social Whirl of 'White' Yokohama After Iwakura's Return.” In: Ian Nish (ed.) The Iwakura Mission in America and Europe. A New Assessment. Taylor and Francis e-Library edition (Japan Library, Curzon Press Ltd., 1998), 113-118.

Fung Yu-lan 2003. A kínai filozófia rövid története. [Ford. Antóni Csaba] Budapest: Osiris.

Havens, Thomas R. 1970. Nishi Amane and Modern Japanese Thought. Princeton: Princeton University Press.

Hirakawa Sukehiro 2007. „Japan's Turn to the West.” In: Marius B. Jansen (ed.) The Cambridge History of Japan. Vol. 5. The Nineteenth Century. Cambridge: Cambridge University Press, 432-498.

Howland, Douglas 2001. „Translating Liberty in Nineteenth-Century Japan.” Journal of the History of Ideas 62/1: 161-181.

Howland, Douglas 2002. Translating the West. Language and Political Reason in Nineteenth-Century Japan. Honolulu: University of Hawai'i Press.

Huish, David J. 1972. „The Meirokusha. Some Grounds for Reassessment.” Harvard Journal of Asiatic Studies 32: 208-229.

Jamadzsi Maszanori 1989. Japán. Történelem és hagyományok. Budapest: Gondolat.

Jansen, Marius B. 2007. „Japan in the Early Nineteenth Century.” In: Marius B. Jansen (ed.) The Cambridge History of Japan. Vol. 5. The Nineteenth Century. Cambridge: Cambridge University Press, 87-115.

Jansen, Marius B. - Rozman, Gilbert 1988. „Overwiev.” In: Marius B. Jansen - Gilbert Rozman (eds.) Japan in Transition from Tokugawa to Meiji. Princeton: Princeton University Press, 3-26.

Karlgren, Bernhard 1996. Grammata Serica Recensa. Taipei: SMC Publishing Inc. 
Katō Shūichi 加藤周一 1991. „Meiji shoki no hon’yaku. 「明治初期の翻訳」[Fordítás a korai Meiji-érában].” In: Katō Shūichi 加藤周一 / Maruyama Masao 丸山真男 (eds.) Hon'yaku no shisō 翻訳の思想 [A fordítás az eszmetörténetben] (Nihon kindai shisō taikei 日本近代思想体系 15.) Tōkyō: Iwanami Shoten, 342-380.

Klaudy Kinga 1994. A forditás elmélete és gyakorlata. Budapest: Scholastica.

Kōno Yūri 河野有理 2011. Meiroku Zasshi no seiji shisō. Sakatani Shiroshi to „,dōri” no chōsen 明六雑誌の政治思想. 坂谷素と「道理」の挑戦 [A Meiroku Zasshi politikai gondolkodása. Sakatani Shiroshi és az „ész” kihívása]. Tōkyō: Tōkyō Daigaku Shuppankai.

Kósa Gábor 2013. „A konfucianizmus.” In: Kósa Gábor - Várnai András (szerk.) Bölcselök az ókori Kínában. Budapest: Magyar Kína-kutatásért Alapítvány, 38-121.

Koyasu Nobukuni 子安宣邦 2010. Shisōshika ga yomu rongo. „Manabi” no fukken 思想史家が読む論語.「学び」の復権 [A Lunyu az eszmetörténész olvasatában. A „tanulás” rehabilitációja]. Tōkyō: Iwanami Shoten.

Löwith, Karl 2013. „Japans Verwestlichung und moralische Grundlage.” In: Karl Löwith Der Japanische Geist. Berlin: Mathes \& Seitz, 48-74.

Macfarlane, Alan 2013. Fukuzawa Yukichi and the Making of the Modern World. CreateSpace Independent Publishing Platform.

Mártonfi Ferenc 1971. „A kínai szófaj kérdéséhez: A szófaj mint különös.” Magyar Filozófiai Szemle 1971/1-2: 242-257.

Maruyama Masao 丸山真男 1991. „Amerika dokuritsu sengen” (bunkenkaidai) $「 ア メ ~$

リ力独立宣言」（文献解題） [,Amerikai függetlenségi nyilatkozat” (szövegmagyarázat)]. In: Katō Shūichi 加藤周一 / Maruyama Masao 丸山真男 (eds.) Hon'yaku no shisō 翻訳の思想 [A forditás az eszmetörténetben] (Nihon Kindai Shisō Taikei 日本近代思想体系15.) Tōkyō: Iwanami Shoten, 406-413.

Morimoto Jun'ichirō 森本順一郎 2009. Nihon shisōshi 日本思想史 [Japán eszmetörténet]. Tōkyō: Miraisha.

Nihon shisōshi jiten 日本思想史辞典 [Japán eszmetörténeti szótár] 2009. Ishige Tadashi 石毛忠 et. al. (eds.) Tōkyō: Yamakawa Shuppansha.

Numata Jirō 沼田次郎 1989. Yōgaku 洋学 [Nyugat(i) tudomány]. Tōkyō: Tōkyō Daigaku Shuppankai.

Ōhashi, Ryōsuke 1999. Japan im interkulturellen Dialog. München: Iudicum.

Ōhashi, Ryōsuke 2014. „Ja und Nein zur Frage: Gibt es in der Philosophie »West« und »Ost«? Deutsch-japanische Denkwege im Rück- und Ausblick.” [Előadás a XXIII. Deutscher Kongress für Philosophie keretében, Westfälische Wilhelms-Universität, Münster, 2014.10.02.]

Okamoto Takashi 岡本隆司 2015. Nicchū kankeishi 日中関係史 [A japán-kínai kapcsolatok története]. Tōkyō: PHP Shinsho.

Okubo Toshiaki 大久保利謙 2007. Meirokusha 明六社 [A Meiji Hat Társaság]. Tōkyō: Kōdansha.

Ooms, Herman 1997. „Neo-Confucianism and the Formation of Early Tokugawa Ideology: Contours of a Problem." In: Peter Nosco (ed.) Confucianism and Tokugawa Culture. Honolulu: University of Hawai'i Press, 27-61. 
Rubinger, Richard 1988. „Education: From One Room to One System.” In: Marius B. Jansen - Gilbert Rozman (eds.) Japan in Transition from Tokugawa to Meiji. Princeton: Princeton University Press, 195-230.

Salát Gergely 2016. Büntetöjog a Han-kori Kinában. Budapest: Typotex.

Satō Masahide 佐藤正英 2003. Nihon rinri shisōshi 日本倫理思想史 [A japán etikai gondolkodás története]. Tōkyō: Tōkyō Daigaku Shuppankai.

Spalding, Matthew 2011. Az amerikai függetlenségi nyilatkozat és az alkotmány alapelvei. [Ford. Csonka Judit] Budapest: Common Sense Society - Századvég.

Swale, Alistair 2000. The Political Thought of Mori Arinori. A Study in Meiji Conservativism. London - New York: Routledge.

Szabó Balázs (ford., bev.) 2011. „Motoori Norinaga: Naobi no mitama.” Vallástudományi Szemle 2011/3: 149-168.

Szabó Balázs 2015. „Bevezetés a szamurájok oktatásába: Yamaga Sokō Bukyō shōgakuja.” Távol-keleti Tanulmányok 2015/2: 27-49.

Szabó Balázs 2016. Test és tudat. A japán harcmüvészeti filozófia hajnala. Debrecen: Torii.

Takó Ferenc 2013. „Mit jelent a fordítás? Öri Sándor: Lun jü.” Magyar Filozófiai Szemle 2013/1: 183-191.

Takó Ferenc 2014. „Az amerikai demokrácia és a kínai despotizmus.” Holmi 2014/4: 402-429.

Takó, Ferenc 2015. „Distinguishing Names - Identifying Reigns: The Role of Ten/Tian in Ogyū Sorai's Bendō and Benmei." In: Papp Melinda (ed.) Encounters with Japan. Japanese Studies in the Visegrad Four Countries. Budapest: ELTE University Press - Eötvös Loránd University, 223-253.

Totman, Conrad 2006. Japán története. Budapest: Osiris.

Tozawa Yukio 戸沢行夫 1991. Meirokusha no hitobito 明六社の人びと [A Meiji Hat Társaság alakjai]. Tōkyō: Tsuiji Shokan.

Várnai András 1984. „Az emberi törvény és a természeti törvények needhami felfogásához.” Filozófiai Figyelö 6/3: 101-107.

Várnai András 2011. „Matteo Ricci és a korai jezsuita Kína-misszió.” In: Patsch Ferenc SJ. (szerk.) Misszió, globalizáció, etika. Matteo Ricci szellemi öröksége. Budapest: JTMR Faludi Ferenc Akadémia/L'Harmattan, 51-68.

Wakabayashi, Bob Tadashi 1984. „Katō Hiroyuki and Confucian Natural Rights, 18611870." Harvard Journal of Asiatic Studies 44/2: 469-492.

Yamakawa Hideya 山川偉也 1994. „Nishi Amane »Chichikeimō« ni miru seiyōkeishiki ronrigaku no honpō he no dōnyū ni tsuite 西周『致知啓蒙』に見る西洋形 式論理学の本邦への導入について [A nyugati típusú logika-tudomány bevezetése hazánkban Nishi Amane »A tudás kiterjesztésének megvilágítása« című munkájának tükrében"]." St. Andrew's University, Bulletin of Research Institute 19/3: 35-46.

Yanabu, Akira 柳父章 2001.,Goddo”wa kami ka jōtei ka「ゴッド」は神か上帝か [Kami vagy Shangdi-e „God”?]. Tōkyō: Iwanami Shoten.

Yanabu, Akira 2009a. Hon'yakugo seiritsu jijo 翻訳語成立事情 [A fordítási terminusok létrejöttének körülményei]. Tōkyō: Iwanami Shoten. 
Yanabu, Akira 2009b. „Translation in Japan: The Cassette Effect.” TTR: traduction, terminologie, rédaction 22/1: 19-28.

Zhang, Wei-bin 2010. Fukuzawa Yukichi. The Pioneer of East Asia's Westernization with Ancient Confucianism. Baltimore: Publish America. 